\title{
Do banking groups shape the network structure? Evidence from Turkish interbank market ${ }^{\text {th }}$
}

\author{
Tuba Pelin Sümer ${ }^{\mathrm{a}, \mathrm{b}}$, Süheyla Özyıldırım ${ }^{\mathrm{a}} *$ \\ ${ }^{\text {a }}$ Faculty of Business Administration, Bilkent University, Cankaya 06800, Ankara, Turkey \\ ${ }^{\mathrm{b}}$ Banking and Financial Institutions Department, Central Bank of the Republic of Turkey, Ulus 06050, Ankara, Turkey
}

\section{A R T I C L E I N F O}

\section{Keywords:}

Interbank markets

Core-periphery

Ownership structure

Financial regulation

\begin{abstract}
A B S T R A C T
Using a unique exposure data on Turkish banking system (disaggregated according to bank ownership structure and instrument level), we study the effects of ownership structure on the interbank network structure. During the sample period of 2003-2017, we observe that foreign and state deposit banks are the dominant institutions shaping the structure of the network under different contracts. Foreign banks, in particular, have a higher coreness vector in derivative exposures through their comparative advantage in offsetting derivative transactions. Moreover, our findings suggest that when foreign investors acquire domestic banks, the network structures of the acquired bank change considerably. We also present evidence that local and Basel III regulations play a significant role in the formation of the network structure through liquidity channel. We found highly liquid large banks and well-capitalized non-large banks have become more centralized in the interbank security market. The central bank's efforts to restore liquidity in the money markets during and after the global financial crisis seem to have increased the central role of foreign deposit banks in the overnight lending market against state and large private deposit banks.
\end{abstract}

\section{Introduction}

Banks rely on interbank links to protect themselves from random liquidity shocks as well as to increase the proportion of their assets held in long-term high profit assets. However, interbank relations may cause solvent banks to become insolvent due to the contagion effect. Also, an insolvent bank may be rescued since some part of the losses are transferred to the other banks which would bring about inefficiency and create moral hazard problems (Allen \& Babus, 2009; (Freixas, Parigi, \& Rochet, 2000)). Despite its obvious relevance to policymakers, empirical research on the interconnectedness of the banking system had been underscored up until the recent global financial crisis.

Theoretical literature focuses on understanding of the relationship between the structure of the interbank network and the propagation of contagion. Allen and Gale (2000) show that in a structure that is "complete", in which banks are all linked to each other, the system is less prone to contagion. In other words, in the case of the failure of a bank due to a higher than expected liquidity shock, it is argued that the remaining banks in the system insure themselves better against liquidity shocks since their losses are shared with more banks; in this way, they can absorb the impact of the failure. They also introduce two highly stylized network structures, i.e., incomplete and disconnected market structures, and show the non-monotonic relationship between the network structure and the resilience of the network. Freixas et al. (2000) introduce another network structure in which there are money centers or core banks and the remaining banks in the periphery are linked to these core banks, but not to each other. They argue that this network structure may have a susceptible mechanism for the propagation and amplification of shocks.

Following the theoretical models, a strand of empirical studies explored the contagion effect of the failure of a bank or a banking group on the system via simulations (see e.g. Furfine, 2003; Degryse \& Nguyen, 2007; Lelyveld \& Liedorp, 2006; Upper \& Worms, 2004; Cont, Moussa, \& Santos, 2013). In addition to the contagious failure studies,

\footnotetext{
This paper was presented in the 6th Meeting of the German Network for New Economic Dynamics (GENED) and 9th International Conference of the Financial

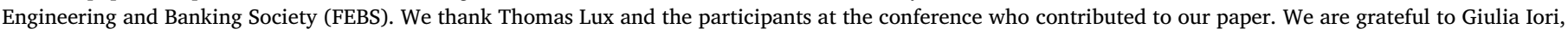

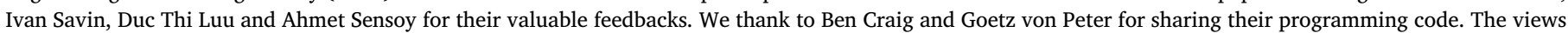

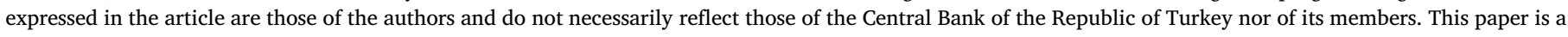
part of Tuba Pelin Sümer's Ph.D. study in the Faculty of Business Administration in I.D. Bilkent University.

* Corresponding author.

E-mail addresses: pelin.sumer@tcmb.gov.tr (T.P. Sümer), suheyla@bilkent.edu.tr (S. Özyıldırım).
} 
the newly evolving literature investigates whether some "typical" network structures explain the actual networks in the banking systems using unique bilateral interbank data. In the literature, the typical financial network structures proposed are random networks, scale-free networks, core-periphery model and nested-split graph which are based on random interaction, preferential attachment, intermediation and counterparty reliability concepts respectively. ${ }^{1}$

These seminal theoretical papers take the structure of financial networks as exogenously given and do not explicitly focus on the formation of financial networks. Acemoglu, Ozdaglar, and Tahbaz-Salehi (2015), however, emphasize the importance of the endogenous formation of strategic interbank linkages between different types of institutions, such as deposit-taking institutions, investment banks, and other specialized financial institutions in different interbank lending forms and maturity. In this paper, we aim to contribute to this literature by empirically investigating how the network structure between banks is shaped using a unique data set from Turkey. We rely on the importance of different interbank contracts as well as financial institutions with different ownership and business models in influencing the network structure.

In the literature, there is a paucity of studies showing the existence of multi-layer network structures according to the maturity, the nature (secure/unsecured) and/or the type of the contracts due to lack of data availability (Aldasoro \& Alves, 2018; Bargigli, Di Iasio, Infante, Lillo, \& Pierobon, 2015; Langfield, Liu, \& Ota, 2014; Montagna \& Kok, 2016). However, it is well-recognized that macro prudential policies benefit from the consideration of subnetworks and the extent that transmission channels across layers. In this paper, we examine the multi-layer network structure according to bank ownership in order to address the impact of a strong presence of foreign and state-owned banks on the network of the interbank activities. Turkey is an interesting country in which to study the network structures of several interbank contracts among different financial institutions since there are state-owned, private and foreign banks as deposit collecting institutions; investment and development banks as non-deposit collecting institutions; and participation banks collecting deposits (deposits are called as "participation fund" and these banks work according to Sharia rules). Turkish banks have learned the importance of establishing sustainable interbank lending relationships since the last banking crisis in 2001 which ended with the collapse of 18 banks one of which was a medium-size bank (the ninth largest), Demirbank (Akyüz \& Boratav, 2003; Dornbusch, 2001). Demirbank was holding $15 \%$ of total government bonds and funding these investments in the overnight interbank market. The failure of interbank borrowing and the increase of interest rates to $7000 \%$ caused the collapse of the bank (Gençay \& Selçuk, 2006). After the crisis, the regulatory framework was strongly improved and different banking groups formed interbank lending relationships to manage their liquidity and currency risks, using several new interbank contracts.

First we show that similar to previous evidence, ${ }^{2}$ the core-periphery (CP) structure, with a number of highly interconnected (core) banks holding the market together, gives a better fit to the Turkish interbank network compared to the random and scale-free structures. The existence of $\mathrm{CP}$ structure might be expected for any emerging country considering that a few large banks tend to dominate these markets. Nevertheless, it is interesting to observe how large banks in the core set care their link formations to have sustainable and long-term funding

\footnotetext{
${ }^{1}$ For detailed information on random networks see Erdös and Renyi (1959), for scale-free networks see Barabasi and Albert (1999), for core-periphery networks see Craig and von Peter (2014) and for nested-split graphs see König, Tessone, and Zenou (2014).

${ }^{2}$ See e.g. Craig and von Peter (2014) for Germany; In't Veld and van Lelyveld (2014) for Netherlands; Fricke and Lux (2015) for Italy; Langfield et al. (2014) for UK; Silva, de Souza, and Tabak (2016) for Brazil; Martinez-Jaramillo, Alexandrova-Kabadjova, Bravo-Benitez, and Solorzano-Margain (2014) for Mexico and Aldasoro and Alves (2018) for a group of European countries.
}

relationships even if their exposures might be small compared to the more advanced countries. Second, commonality analysis shows that the set of core banks identified vary under different interbank contracts, suggesting the existence of instrument-based networks.

Our paper contributes to the literature in three ways. We study for the first time networks between different banking groups. To our knowledge, previous studies do not show whether certain banking groups have a comparative advantage in offsetting exposures under different interbank contracts. For example, we find that foreign banks play an important role, especially in shaping the over-the-counter (OTC) FX derivatives markets. One of the key lessons from the failure of Lehman Brothers in the unsecured interbank market, the repurchase market and the OTC derivatives markets is that a great deal of damage to the financial system might be inflicted in the absence of transparency in bilateral transactions. So, a closer look at the formation of interbank network structure would then be very important in countries that have seen a significant increase in foreign bank presence. Development banks, which are generally state-owned, invest their excess funds in state-owned deposit banks in terms of deposit and state-owned banks prefer to invest in government bonds instead of bank bonds, increasing the concentration of risks in the state-owned institutions. A move to support state-controlled banks may lead to waste and slow growth as well as a raise in systemic risk as Fannie and Freddie, and the Spanish cajas so clearly show (Calomiris, 2011).

Our second contribution is the finding that the entry of foreign banks seems to change the overall network structure. Over the last two decades, foreign banks have significantly increased their participation in the emerging markets raising questions about their potential benefit especially in the credit markets. Since the global financial crisis of 2007, global banks have attracted marked interest from policy makers, researchers, and other financial sector stakeholders. We found that before the global financial crisis, there was intense foreign interest in the Turkish interbank market, and that after foreign purchases in that period, a change in the controlling shareholders in the acquired bank for most of the banks caused the network to change. However, after the global crisis, the acquisition of existing foreign banks by another foreign bank or increasing shares of foreign stakes in the existing banks did not significantly change the existing network structure. To our knowledge, this is the first time that the effect of foreign bank acquisitions on the change in network relations has been analyzed.

As a final contribution, we present evidence that the local and international regulatory rules seem to shape the network structure. Banks having lower loan to deposit ratio, or higher liquidity coverage ratio (LCR) (defined according to Basel standards), make more investments in bank bonds since they have ample sources that can be used in bond investments. We find that there is a close relationship between the interbank repo amount and interest rate differential in the market since some banks find an arbitrage opportunity due to the bank limits in repo transactions with the Central Bank. Our findings on the relation between regulations and interbank relations are also consistent with the literature as documented by Gabbi, Iori, Jafarey, and Porter (2015) for the effects of regulatory leverage ratio and Bonner (2016) for the increased preference for government bonds after capital and liquidity regulations.

The remainder of the paper is organized as follows: In Section 2, we introduce the data set and highlight the Turkish banking structure as well as important features of the interbank market. Section 3 summarizes the CP network structure analysis, using all types of banks and financial instruments in Turkey. Section 4 discusses the network structure of instrument-based relations when banks are grouped according to their banking groups. The factors prevalent in explaining the coreness of a bank and the effect of foreign bank entries are analyzed in this section. Section 5 concludes the paper. 


\section{Data description}

In this study, we use monthly transaction-level data that are collected by the Banking Regulation and Supervision Agency of Turkey. In the analysis, we cover different types of interbank contracts namely repo transactions, deposits, loans, securities, derivatives and other offbalance sheet items. Derivatives are swaps, forwards, futures and options used by banks to hedge interest rate and currency type risks. Other off-balance sheet items are the ones that are accounted in off-balance sheet other than derivatives such as letters of guarantee, bank acceptance, letters of credit and other guarantees. Securities refer to bond issuances, equity investments and credit-linked notes. Deposits cover both time and demand deposits. Loans include syndication loans, securitization loans, subordinated loans, foreign trade financing loans and other loans. Repo transactions are used to borrow or lend short-term liquidity in exchange for securities.

The interbank data is based on individual bank reporting where reasonable doubts exist as to the correctness or the completeness of the data. A bank may report the exposure amount or type of exposure in an incorrect way, which is a common problem for all countries collecting transaction level data. In the network analysis, it is extremely important to use a matching algorithm to obtain pairwise transaction data. In our dataset, since most of the transactions are reported as double entry, i.e., banks are reporting both their receivables and payables; we are able to use this matching algorithm. We match more than $70 \%$ of the available transactions since the beginning sample period of January 2003 (see Table 1).

There are three main counterparties for the interbank exposures of banks. These are central banks, foreign banks abroad, and domestic

Table 1

Number of transactions.

\begin{tabular}{lccc}
\hline & & \multicolumn{2}{l}{ Number of transactions } \\
\cline { 3 - 4 } Transaction types & Reporting period & Before match & \multirow{2}{*}{ After match $^{\dagger}$} \\
\hline \multirow{2}{*}{ Repo } & $2003: 1-2017: 12$ & 56,813 & 47,624 \\
Deposit & $2003: 1-2017: 12$ & 159,166 & 87,341 \\
Loan & $2003: 1-2017: 12$ & $1,552,545$ & $1,138,541$ \\
Security & $2007: 1-2017: 12$ & 64,138 & 64,138 \\
Derivative & $2014: 1-2017: 12$ & 40,133 & 40,133 \\
Other off-balance sheet & $2003: 1-2017: 12$ & $2,419,150$ & $2,419,150$ \\
Total & & $4,291,945$ & $3,796,927$ \\
\hline
\end{tabular}

Notes: Source of the data is the Banking Regulation and Supervision Agency of Turkey. Reporting period for interbank contracts are different due to data gaps. Total number of transactions in the dataset are reported in the table. After match data show the available data after the cross-check procedure is carried out. The counterparty banks are determined using their tax numbers, swift codes or if they are not available in the data set using their names (this is a daunting task because a counterparty name can be written in many different formats, shortcuts or extensions). Interbank loan, deposit and repo transactions are reported in one dataset which is available for the period 2003-2017 in a monthly frequency. In that dataset domestic banks are reporting their receivables and payables, which helps to match the reporting of lender/borrower banks. To exemplify, if Bank A is reporting a receivable of $\$ 100$ from Bank B in loan type, Bank B should report this as $\$ 100$ payable to Bank A in loan type for an accurate reporting. Since this dataset covers a big portion of total interbank exposures, it is important to match the lender/borrower bank reporting and work with correct networks. The transactions that have same borrower/lender bank set, exposure type (loan/deposit/repo), exposure origination date $\mp 2$ day, exposure maturity date $\mp 2$ day, exposure amount up to $1 \%$ error and currency are assumed matched. In all the analysis these matched transactions are used. There may be many transactions between a lender bank and borrower bank in a specific month and interbank contract. For example, bank A may have opened a time deposit account on July 15, 2009 and a demand deposit on July 22, 2009 in Bank B. So, we band together the matched transactions between the same borrower/lender set for each month and instrument to form monthly networks between banks. banks. In this study, we only examine the exposures among banks that are operating in the Turkish domestic market. For the last ten years, the Central Bank of Turkey has been the main liquidity provider, i.e., the average net funding of central bank is on average four percent of the total banking asset. As emphasized by Allen, Carletti, and Gale (2009), the role of central banks in the interbank markets has changed since the global crisis and has become massively intervening. Considering the other motivations of the Central bank in the financial network such as restoring the normal functioning of the short-term interbank markets, we exclude the Central Bank of Turkey in our analysis. The foreign banks abroad are also excluded due to the unavailability of data between these and banks operating in the domestic market.

As of December 2017, there are 50 banks operating in Turkey (three state-owned deposit banks, 10 private deposit banks, 20 foreign deposit banks, five development banks, seven investment banks, and five participation banks). The top seven banks, three of which are state-controlled deposit banks, hold more than $70 \%$ of the banking sector's total assets, loans and deposits in Turkey. The current fragmented structure shaped slowly over the last fifteen years although the number of banks operating in Turkey has been nearly stable. As in most of the emerging economies, foreign deposit banks have expanded their presence since 2005 through acquiring private deposit banks rather than greenfield investments. They hold almost half of the banks in numbers but only have a $24 \%$ market share just after the Spanish BBVA Group acquired one of the largest private deposit banks in 2015.

The privately-owned deposit banks comprise the largest share of total banking assets (i.e., 34.7\% in 2017). Another large banking group is that of the state-owned deposit banks, which has held almost $30 \%$ of the total banking assets for the last fifteen years. The number and size of participation banks are also very stable over the sample period. These banks hold less than five percent of the banking sector assets. Up to 2016, only three foreign and one private participation banks had been operating in the market, however, in that period, two state-owned participation banks (which are subsidiaries of state-owned deposit banks) entered the market, changing the presence of state-owned in the industry both in size and its structure. There was only one private participation bank operating in Turkey until July 2016, and their operations were ceased due to a failure to comply with the regulatory procedures. $^{3}$ The last group, that of investment and development banks, is also very stable in number and share of asset size of the industry. While development banks are generally state-owned, investment banks have either private or foreign ownership.

Fig. 1 presents all of the interbank relations between domestic Turkish banks at the beginning of the sample period (January 2003) and the ending (December 2017). As time evolved, the interbank network became more connected and the comparative edge weights for some bank relations became stronger. The total interbank exposures among banks was 80 billion Turkish Lira (TL) or the equivalent of 21.2 billion US dollar as of December 2017, which accounts for about two percent of the total banking assets. Fig. 2 shows the amount of total lending (sum of each bank's interbank lending) and the total number of links in the Turkish interbank market, which has been growing rapidly especially since 2010. At the end of 2017, the instrument-based breakdown of interbank exposures was as follows: $31 \%$ deposit, $20 \%$ security, ${ }^{4} 18 \%$ derivative, $15 \%$ loan, $11 \%$ other off-balance sheet items and six percent repo. The breakdown based on number of links changes

\footnotetext{
${ }^{3}$ Participation banks are grouped as state-owned participation banks and foreign participation banks. Not to reveal information about the private participation bank by grouping alone, we decided to group this bank with the other foreign participation banks.

${ }^{4}$ Before October 2010, only investment and development banks could issue bonds. This limited the size of bank bond issuances and security type exposures were mainly in type of equity investments and credit linked notes. After the change of regulation allowing bond issuance of other banks, bank bond issuances has started to increase.
} 


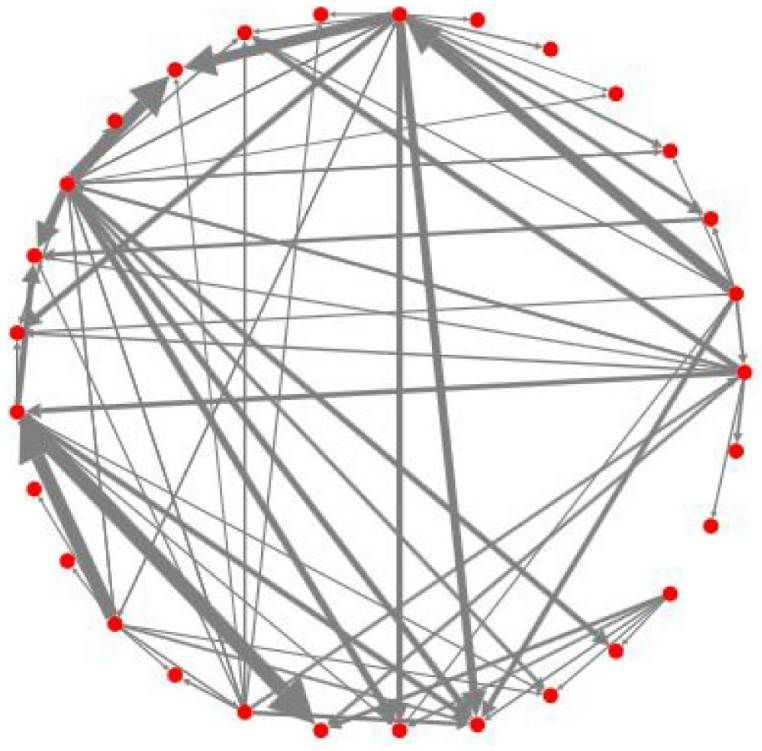

(a) January 2003

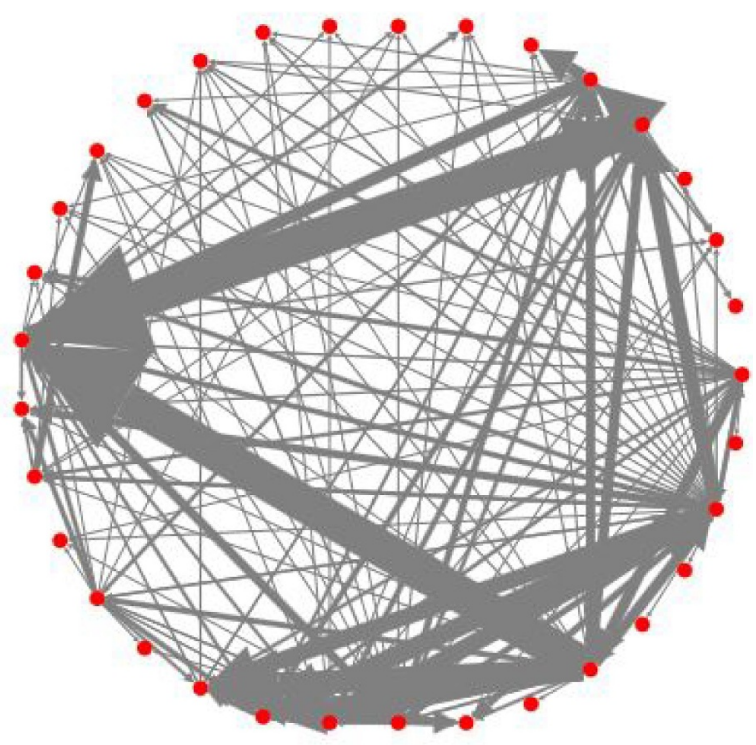

(b) December 2017

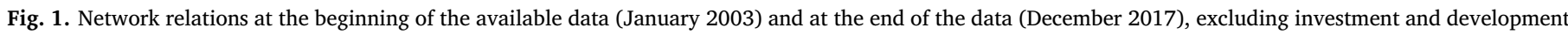
banks. Arrow size shows the comparative weight of the relation compared to other relations.

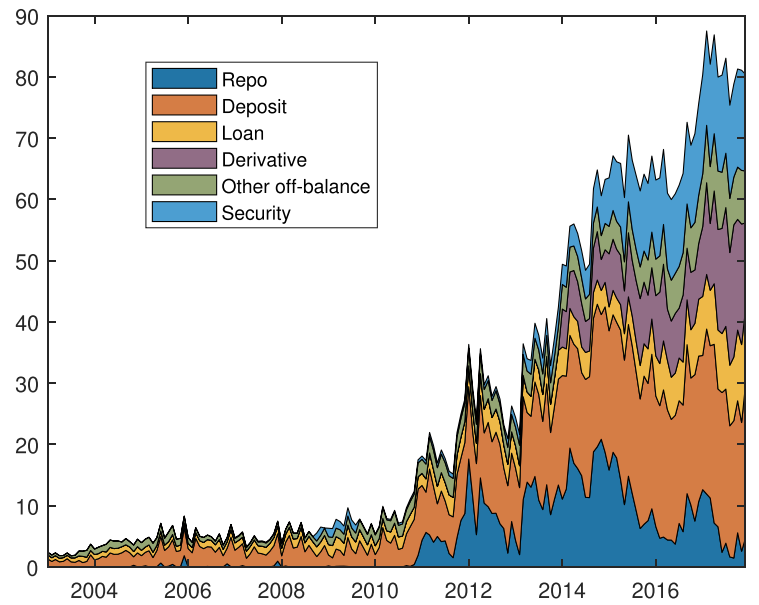

(a) Interbank Exposures (Billion TL)

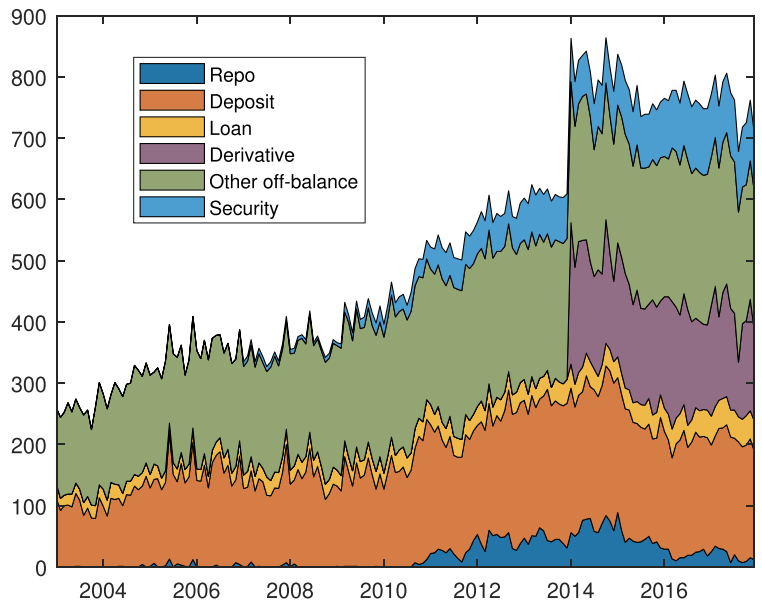

(b) Number of Interbank Links

Fig. 2. Breakdown of interbank exposures.

a little, mainly due to a higher number of links in smaller amounts in some type of instruments: $32 \%$ other off-balance sheet items, $25 \%$ deposit, $21 \%$ derivative, $13 \%$ security, seven percent loan, and two percent repo.

Fig. 3 shows network density (ratio of the total number of actual links in the interbank market over the total number of possible links) through time in Turkey. While Fig. 3a shows the density of total network which is constructed by summing all exposures in the instrumentbased networks, density of each instrument-based network is given in Fig. 3b. The density of Turkish interbank network has increased through time, with on average density becoming $14 \%$ and reaching $18 \%$ as of December 2017. The number of banks, business models, and/ or types of banks are important determinants of the density of a network. Since there is no regional bank in Turkey, the number of banks is relatively small but the network density seems to be comparable to the other countries. ${ }^{5}$ In terms of the density of interbank instruments, other offbalance sheet items have the highest density. This suggests that many banks to be connected over these instruments (Fig. 3b). Moreover, the densities of deposits and derivatives are relatively higher than the densities of repo, securities and loan contracts during the sample period.

\footnotetext{
${ }^{5}$ Fricke and Lux (2015) study Italian interbank market, in their sample there are about 120 banks and network density is calculated as about $15 \%$. For Mexico, the number of banks is 46 and the density is 26 percent (MartinezJaramillo et al., 2014). The study for German interbank market covers on average 1732 banks, which are mainly in type of savings banks and credit unions and the network density is calculated as 0.66 percent. Langfield et al. (2014) document the network density for UK as three percent, which is composed of 176 banks.
} 


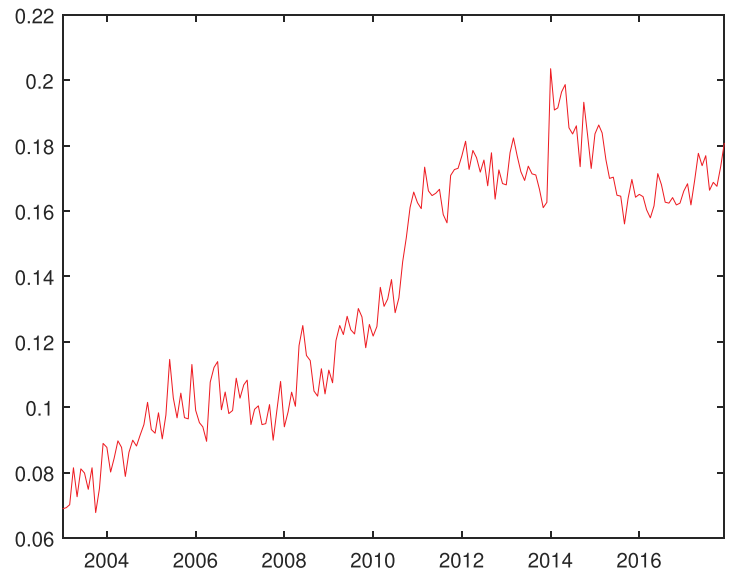

(a) Density of Total Exposures Network

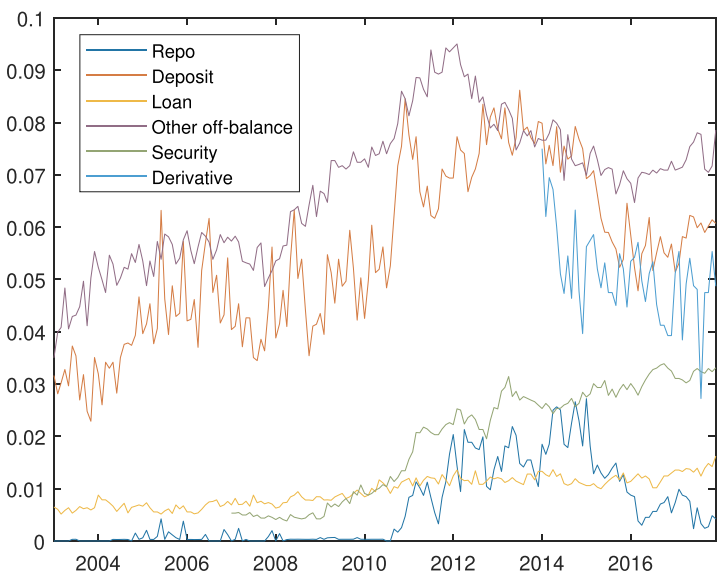

(b) Density of Instrument-based Networks

Fig. 3. Density of interbank transactions.

\section{Network structure}

\subsection{Discrete CP structure analysis}

Interbank markets are often characterized in terms of core-periphery (CP) structure, with highly interconnected (core) banks holding the market together and a periphery of banks, which are connected to the core but not to each other. In this paper, we examine whether $\mathrm{CP}$ structure fits the Turkish interbank market based on total exposures and instrument based exposures using adjacency matrices. We use Craig and von Peter (2014) algorithm, which partitions banks in two groups as core and periphery. This algorithm aims to minimize the error score based on the violation of three characteristics, e.g., bilateral links of core banks; no internal links of periphery banks; and core banks with at least one borrowing and lending link with periphery bank. ${ }^{6}$ Fig. $4 a$ and b presents error scores and the number of core banks identified using interbank network data between all banks and only between deposit collecting banks excluding investment and development banks. Our findings show that the error score of fitting the Turkish interbank market to a CP structure using total interbank exposures decreased over time, especially after the global financial crisis and stabilized around $25 \%$ since 2015 . $^{7}$ During the global financial crisis period, the decrease in the error score has nearly disappeared, which is a similar finding to the literature documenting whether a change in the network density or fitness to $\mathrm{CP}$ structure happened after the crisis. ${ }^{8}$

As seen in Fig. 4b, the number of core banks increased from nine banks in 2003 to 15 banks in 2017. Among 15 core banks, there are seven large banks, three medium-sized banks and five small/microscaled banks. As it may be expected, all of the large banks and some of the medium-sized banks (i.e., 3 out of 9 in our case) are in the core. However, since discrete CP uses only binary links among banks, it appears that five out of 36 small/micro-scaled banks in Turkey are in the

\footnotetext{
${ }^{6}$ See Appendix for the details of CP model and estimation approaches.

${ }^{7}$ As mentioned in Section 2, with Italy, Mexico and Turkey having similar network densities, they also have a similar outlook in terms of fitness of the CP structure. Error scores are 47\% for Italy (Fricke \& Lux, 2015) and 25\% for Mexico (Martinez-Jaramillo et al., 2014) using the same algorithm.

${ }^{8}$ Fricke and Lux (2015) find that there is a structural break in the network density after the global financial crisis. Martinez-Jaramillo et al. (2014) show that while the interbank Mexican market used to fit a CP model more as compared to random and scale-free networks before the failure of Lehman Brothers, after this event the network structure changed to more resemble a scale-free network.
}

core. Similar to our findings, In't Veld and van Lelyveld (2014) document that the core of the Netherlands interbank system always includes all of the large banks, but some small banks are also part of the core. Upper (2011) also states that the criticality or coreness of a bank is not only the function of its size, but also the magnitude of its interbank liabilities as well as its precise location in the market, so small banks can be identified as core. We also find that a similar structure holds for the sample set with only deposit collecting banks (i.e., excluding investment and development banks). ${ }^{9}$

In our instrument-based analysis, we find that except repo and loan contracts, the $\mathrm{CP}$ structure seems to hold for deposits, derivatives, and other off-balance sheet items as well as securities contracts (Table 2). The error score of fitting $\mathrm{CP}$ structure to the derivative exposures is significantly smaller for the last four years (19\%) as compared to the other instruments. The error score of fitting total exposures network to the $\mathrm{CP}$ structure decreases considerably over time mainly due to the inclusion of derivative contracts in the total exposures which has a better fit to the CP structure and decrease in the error scores of other instruments.

To test goodness of fit of the CP model to the actual interbank network, we follow the Monte-Carlo simulations as suggested by Craig and von Peter (2014), In't Veld and van Lelyveld (2014) and Fricke and Lux (2015). The aim of these simulations is to show that the fit (error score) of Turkish interbank market to the core-periphery model is tight (small) enough to conclude that the interbank market has a tiered coreperiphery structure. In that approach, basically first random and scalefree networks are created having similar network properties with the actual network. Then, the error scores of fitting these artificially created networks to CP model is compared with the error scores of fitting actual network to CP model. This approach is indeed the test of a null hypothesis stating that the interbank market fits to a random or scale-free structure. If the error scores of fitting $\mathrm{CP}$ model to the actual network is below a certain percentile of the error scores of fitting CP model to the artificial random or scale-free networks having similar network properties with the actual network, then we can reject the null hypothesis with a significance level. We find that the average error score of fitting

\footnotetext{
${ }^{9}$ We also group transactions into maturity brackets as short-term, long-term, and total, then compare the fitness of the networks. We did not find any significant difference in terms of fitness to CP structure. However since for shortterm contracts, deposit, derivative, and repo have a significant share, and since for long-term contracts, other off-balance sheet, loan and security have a higher portion and different relations and factors are prevalent in each type of contract, core banks identified under different maturity structures are different.
} 


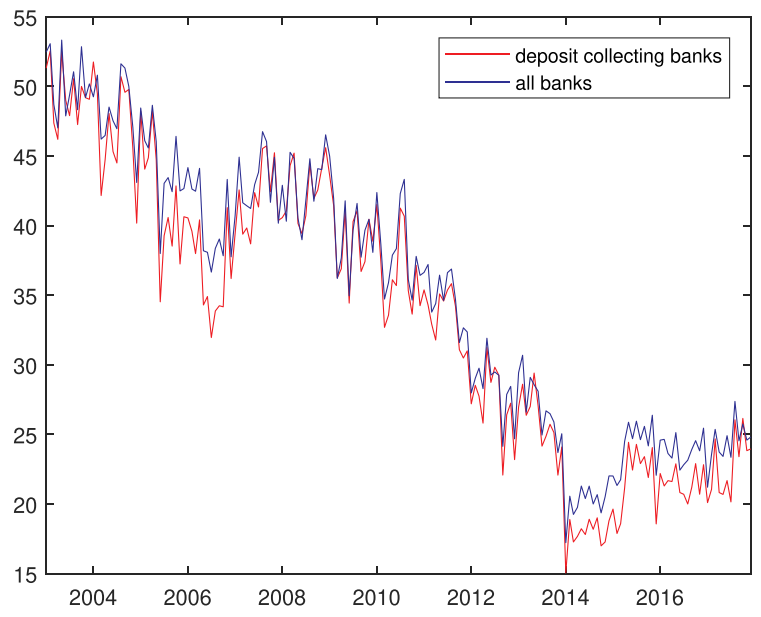

(a) Error Scores

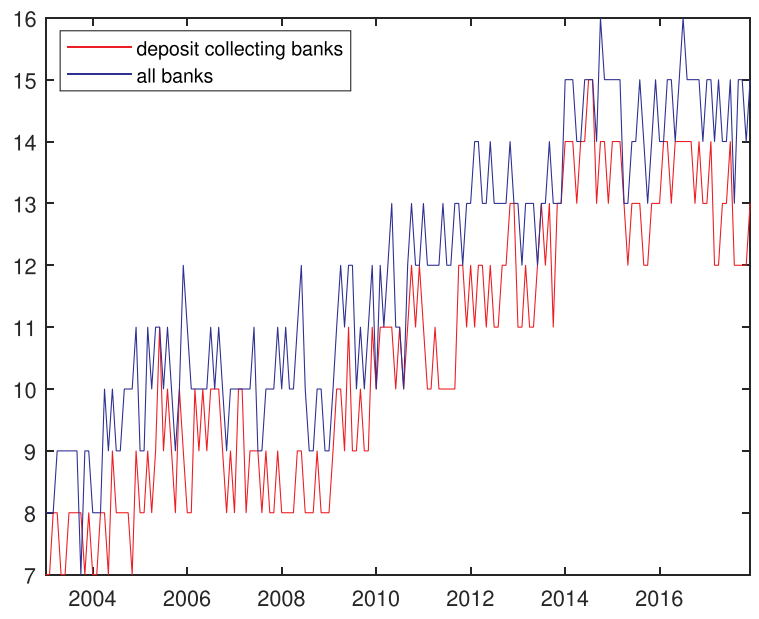

(b) Number of Core Banks

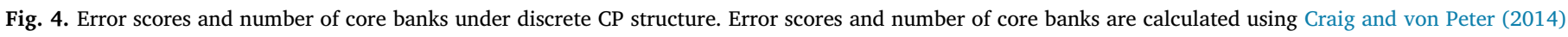
algorithm. Deposit collecting banks refer to the banks excluding investment and development banks.

Table 2

Core banks and error scores for instrument-based networks.

\begin{tabular}{|c|c|c|c|c|}
\hline & \multicolumn{4}{|c|}{ Error scores (percent) } \\
\hline & 2003-2006 & $2007-2010$ & 2011-2013 & 2014-2017 \\
\hline Deposit & 56 & 54 & 47 & 47 \\
\hline Derivative & - & - & - & 19 \\
\hline Other off-balance sheet & 51 & 49 & 43 & 43 \\
\hline Security & - & - & 55 & 46 \\
\hline \multirow[t]{3}{*}{ Total exposures } & 46 & 41 & 30 & 23 \\
\hline & \multicolumn{4}{|c|}{ Number of core banks } \\
\hline & 2003-2006 & $2007-2010$ & $2011-2013$ & 2014-2017 \\
\hline Deposit & 5 & 5 & 7 & 6 \\
\hline Derivative & - & - & & 8 \\
\hline Other off-balance sheet & 7 & 8 & 9 & 9 \\
\hline Security & - & - & 4 & 5 \\
\hline Total exposures & 10 & 11 & 13 & 15 \\
\hline
\end{tabular}

Notes: Repo and loan contracts did not fit to the CP structure and hence they are not reported. Due to a limited number of links in the repo and loan contracts, we could not search for another network structure for these contracts. Derivatives and securities contracts have been reported since 2014 and 2011 respectively in the Turkish interbank market.

a CP structure to a random network having similar properties with total exposures network is $69.1 \%$, and the error score for fitting to a scale free network is $50.1 \%$. The error score for fitting the CP model to the actual network is found as $25 \%$ as of the latest period data (Fig. $4 \mathrm{a}$ ). Indeed, all error scores of fitting $\mathrm{CP}$ model to random and scale-free networks are above $25 \%$. So, we conclude that $\mathrm{CP}$ structure gives a better fit to the Turkish interbank network compared to the random and scale-free structures and the average error score of fitting CP model to the actual network is approximately $1 / 3$ times of the average error score of fitting CP model to a random structure and $1 / 2$ times of the average error score of fitting $\mathrm{CP}$ model to a scale-free structure. For the goodness of fit of instrument-based networks, while deposit, derivative, security and other off-balance sheet item networks all fit to CP model significantly better compared to a random network, except for the derivative network there is no significant difference of the fitness of scalefree and actual networks to the CP model.

Finally, we aim to analyze whether larger banks in terms of their asset size are identified as a core bank. We focus on the period that starts in 2014 to compare the core-periphery assignments found by Craig and von Peter (2014) approach and asset rankings of the banks. This time period allows us to make use of interbank relations in all types of instruments. Moreover, CP structure fits to the actual interbank network with the least amount of error score during the 2014-2017 period. In Fig. 5, we group banks in five groups according to their asset ranks. Then, we calculate the percentage of the months in the 2014-2017 period that the banks in the related asset rank range is identified as a core bank. In the first asset rank range "1-7", there are 7 banks and there are 48 months between 2014-2017 period. The analysis shows that the banks in that range are identified as a core bank in each of the $48 \times 7$ instances, so the percentage is $100 \%$. The banks in the asset rank of " $8-15$ " are identified as core bank $59 \%$ of the instances and the percentage decreases as the asset rank of the banks increase.

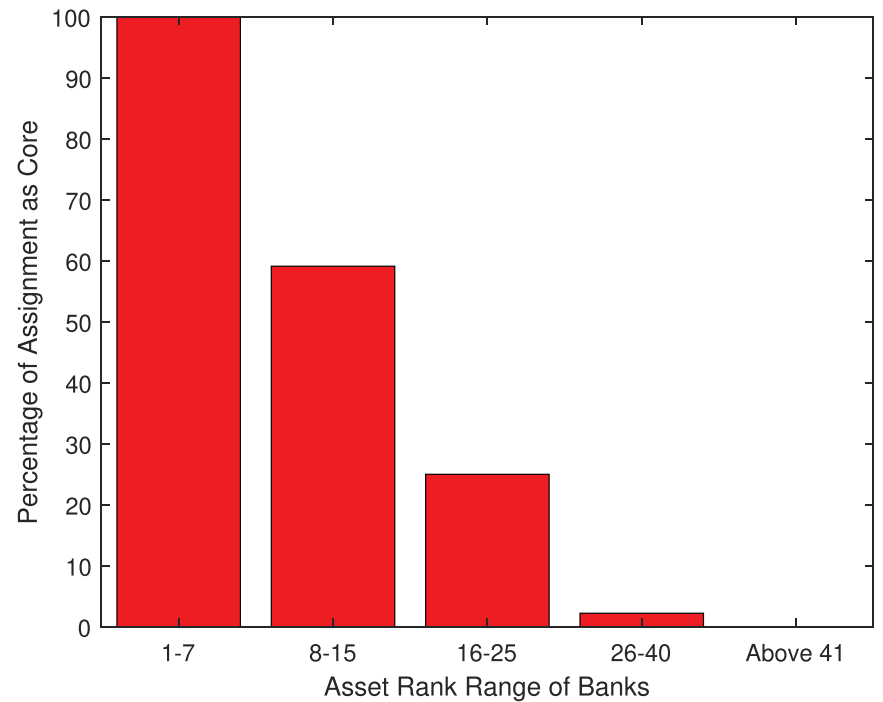

Fig. 5. Relation between asset ranks and percentage of assignment as a core bank in discrete $\mathrm{CP}$ analysis. The figure is plotted using core-periphery assignment and asset rank relations over 2014-2017 period. X-axis shows the range of rankings of the banks according to their asset size. The bank which is largest by asset size takes ranking of one. Y-axis shows the percentage of the months*banks instances in the 2014-2017 period that the banks in the related asset rank range is identified as a core bank. 


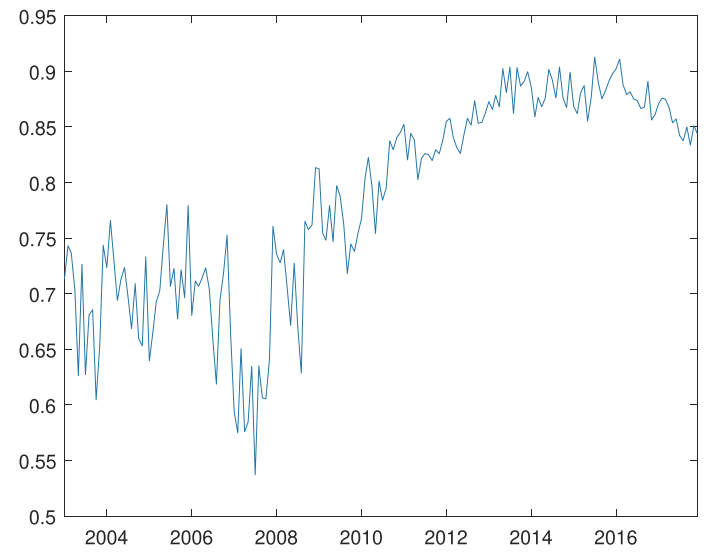

(a) Correlation between Bank Asset Ranking and Total Coreness Ranking

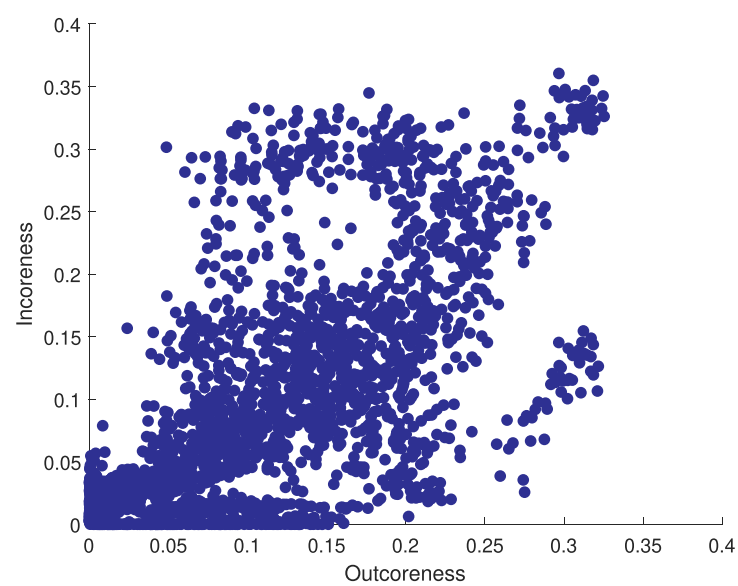

(b) Total Exposures Incoreness vs Outcoreness

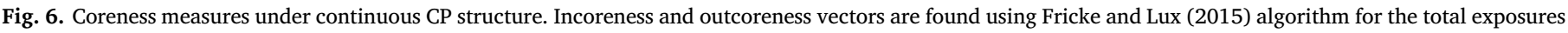
network. Total coreness is the sum of incoreness and outcoreness vectors. See Appendix for the details of the estimation of continuo.

The analysis shows that larger banks are never identified as periphery bank; however some smaller banks can be identified as core banks since they have many links in the discrete $\mathrm{CP}$ analysis.

\subsection{Continuous $C P$ structure analysis}

One limitation of the discrete CP approach for interbank relationship analysis among banks is to consider every interaction, i.e., link, with an equal weight. Considering the nature of the transactions in the banking industry and the heterogeneous size distribution of Turkish banks, we also study continuous CP structure for the Turkish interbank market using the approach introduced by Boyd, Fitzgerald, Mahutga, and Smith (2010). In that approach, a coreness measure is assigned to each bank showing the strength of the bank in the market using weighted network exposures. More precisely, we estimate two coreness measures for each bank namely incoreness and outcoreness respectively showing the importance of the bank in terms of receiving and distributing money in the market.

Similar to the discrete $\mathrm{CP}$ analysis, we examine the relationship between the total coreness measure (the sum of incoreness and outcoreness measures) and the asset size of the banks for the continuous CP structure. The analysis shows that the correlation coefficient increases over time, suggesting larger banks to be more active/connected in the Turkish interbank market (Fig. 6a). For the sake of illustration, we focus on the incoreness and outcoreness values of banks during the period of 2014-2017, each dot showing the values of a bank in a certain period (Fig. 6b). Out of 2625 incoreness/outcoreness values in total exposures, we find that there is a high correlation (68\%) between interbank receivables and payables of the banks in the interbank market.

Fig. $7 \mathrm{a}-\mathrm{f}$ presents the incoreness and outcoreness values of each bank based on interbank instruments. Different from Fig. 6a, the linear relationship between incoreness and outcoreness vectors varies if the networks of specific instruments are considered. Instrument-based incoreness and outcoreness measures indicate the first signs of how bank ownership may shape the interbank network structure in Turkey. For example, in repo transactions, since banks in general have either repo payable or repo receivable, they are located on the $\mathrm{x}$-axis or $\mathrm{y}$-axis most of the time. The banks generally appear either on the short or long side of the repo transaction mainly due to the arbitrage opportunity in the market which will be discussed further in Section 4. Moreover, participation banks have no links in repo transactions since these transactions are not accepted according to Sharia rules.
For deposit exposures, some banks have only deposit receivable, and some have both deposit receivable and payable, but most of the banks have both deposit receivable and payable. In general, development and investment banks are on the $\mathrm{x}$-axis, since they are not allowed to collect deposits; however they invest their funds in other banks to generate income. For loan type exposures, a bank is an important fund supplier for many banks; not so many banks are both fund receiver and fund payable. The general fund supplier bank is on the further point on the $\mathrm{x}$ axis. In security relations, state-owned banks fall into on y axis, since generally other banks hold their issuances; however, they do not hold issuances of other banks. The banks on the $\mathrm{x}$ axis are generally smaller banks that do not issue bonds but holding issuances of larger banks for diversification of their portfolio. There are some banks that are issuing bonds and holding bonds of other banks. There is a linear relationship between incoreness and outcoreness vectors in derivative exposures due to the structure of these transactions. ${ }^{10}$ Finally, in other off-balance sheet transactions there are many banks acting as fund receiver and fund payable, so banks are located inside the graph not on the axis.

\subsection{Commonality of core banks in instrument-based networks}

In this section we examine whether the same banks are identified as core banks in different instrument-based networks. Table 3 presents the commonality of core banks for different instruments identified, using either discrete or continuous $\mathrm{CP}$ approaches. We conduct this analysis for deposits, securities, derivatives and other off-balance sheet instruments during the period of 2014-2017(due to the availability of sufficient observations in these instruments). A commonality analysis shows that the banks that are found as core in different instruments are not so similar, suggesting the existence of different factors in each of them, e.g., ownership structure may shape the network structures.

Among four instrument types, we find that that core banks identified in the other off-balance sheet items are less similar to the core banks found in the other instrument-based networks. Other off-balance sheet network is the one having the highest density among the instruments, so many banks are connected in that network and banks that are not identified as core in the other networks appear to be core in the

\footnotetext{
${ }^{10}$ For example, in a forward transaction, while a bank has TL receivable and USD payable in the agreed forward date, other bank has USD receivable and TL payable. So, the banks entering into a derivative transaction have both receivable and payable.
} 


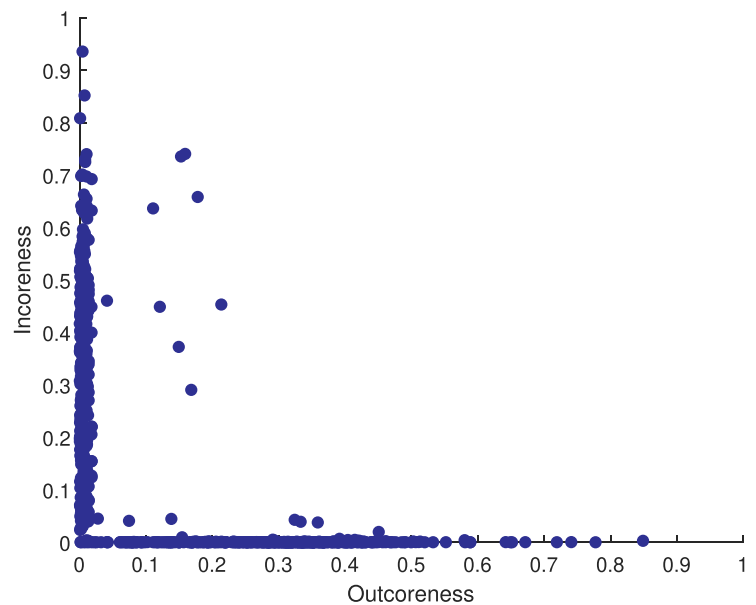

(a) Repo

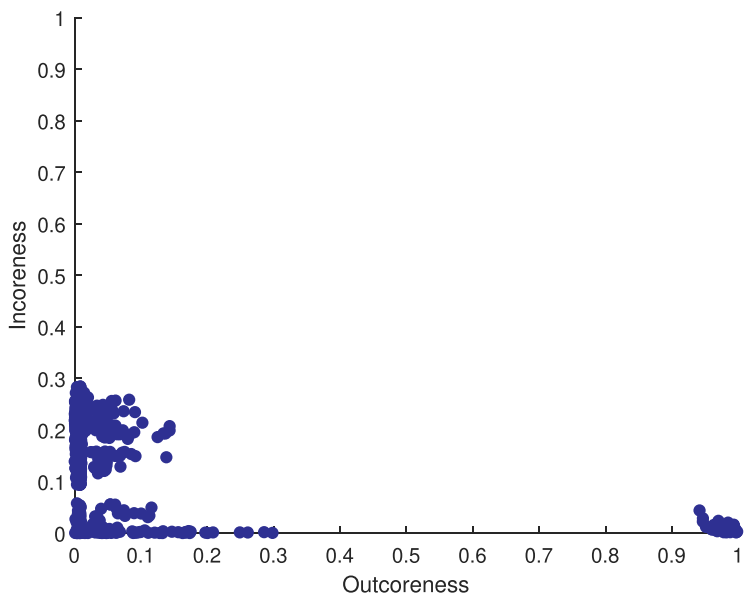

(c) Loan

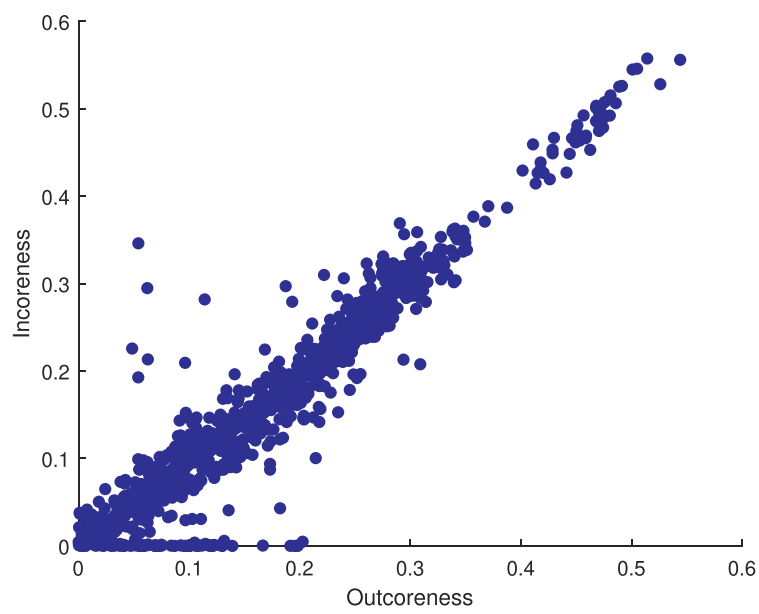

(e) Derivative

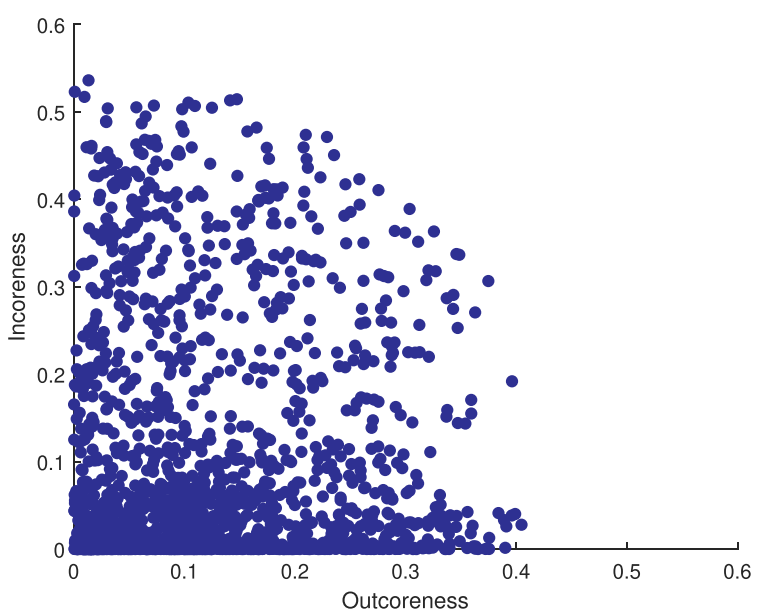

(b) Deposit

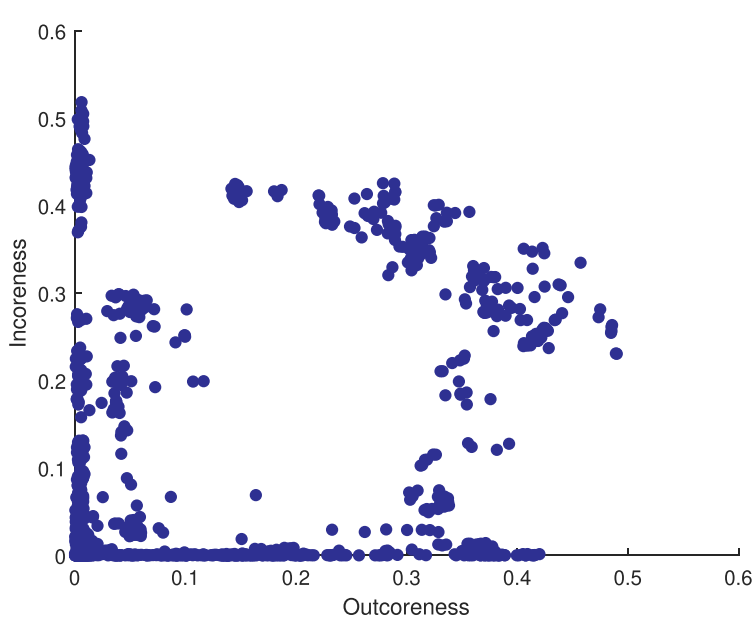

(d) Security

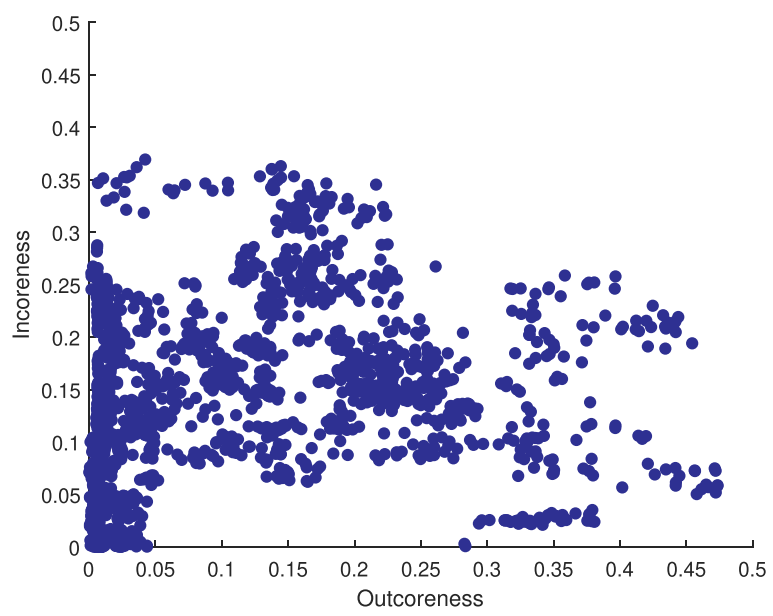

(f) Other off-balance

Fig. 7. Continuous CP model-incoreness vs outcoreness. Each dot shows the incoreness and outcoreness values of a bank in a month during the period of $2014-2017$. 
Table 3

Commonality of core banks in instrument-based networks.

\begin{tabular}{llllll}
\hline & Deposit & Security & Derivative & Other off-balance & Total \\
\hline Deposit & & 36.6 & 32.1 & 23.1 & 42.3 \\
Security & 48.2 & & 33.3 & 22.5 & 27.8 \\
Derivative & 34.4 & 45.6 & & 26.9 & 40.7 \\
Other off-balance & 20.1 & 22.1 & 17.0 & & 51.8 \\
Total & 51.6 & 65.4 & 47.7 & 33.9 & \\
\hline
\end{tabular}

Notes: The upper triangle of the table shows the commonality (in percent) between instruments for the 2014-2017 period for discrete CP analysis, and the lower triangle shows for continuous CP analysis for the same period. Repo and loan contracts did not fit the CP structure and hence they are not reported. Since the number of banks identified as core banks can change for different instruments in discrete $\mathrm{CP}$ analysis, we adopt the following: assume that in the discrete $\mathrm{CP}$ analysis, banks $\{\mathrm{A}, \mathrm{B}, \mathrm{C}\}$ are identified as core banks in the deposit network, and banks $\{B, G\}$ are found to be core banks in the security network for a period. In that example, there is one common core; however, the size of the core banks identified in security and deposit instruments are different, so computation of the commonality is puzzling. As a solution, first we calculate the union of these two arrays which is $\{\mathrm{A}, \mathrm{B}, \mathrm{C}, \mathrm{G}\}$ and the length of this array is four, then we compute the intersection of the arrays which is $\{\mathrm{B}\}$ and length is one, so commonality for deposit and security network in that example is $1 / 4$. The approach is similar in the continuous CP analysis, first we rank the coreness of the banks and the banks having highest five rank are selected as core. We repeat the same approach via identifying the banks ranking in the highest ten as core banks; however, the implications do not change significantly. The average of the commonality ratio as found in the example for each month in the analysis period is reported in the table.

other off-balance sheet items network. For the commonality between the other instruments for the discrete $\mathrm{CP}$ analysis, we see that the maximum commonality is $36.6 \%$ and this is between deposit and security instruments. If we focus on the similarity between total exposures, since the share of other off-balance sheet and deposit exposure links are higher in the total exposures, the similarity in terms of commonality of core banks is higher for those networks with the total exposures network. Commonalities found using continuous CP analysis are higher compared to the discrete analysis, since larger banks having more intermediation power due to their larger balance sheet size become core bank more frequently in continuous analysis. While the similarity between security and total exposures is the lowest in the discrete analysis, it is highest in the continuous analysis. While the share of links of a specific instrument in the total exposures is important for the commonality with the total exposures for discrete $\mathrm{CP}$ analysis, for continuous analysis the share in the total exposures is not so important. Continuous and discrete CP analyses tell us different stories, so in the analysis of the networks, both approaches seem to contribute to better understanding the network structure.

\section{Banking group networks}

In this section, we analyze how the interactions among banking groups (state, private, foreign, state participation, foreign participation, development, and investment banks) shape the network structure under different interbank contracts. First, we limit the time period that the interbank relations are rather stable in the discrete CP model and calculate the network averages using the monthly data for the 2014-2017 period. As seen in Fig. 8, we document interesting interactions among banking groups in the Turkish interbank market.

First, we observe that in the repo transactions, foreign deposit banks are the main fund lenders and state and private deposit banks are the main fund borrowers. These interactions are partly explained by the efforts of the Central Bank (CBRT) to restore the financial intermediation in Turkey. After the global financial crisis, the disruptions in the short-term funding markets prompted central banks worldwide to provide unusual amounts of funds to the real economy. Similarly, CBRT has increased its presence in order to fund the market and become a major fund provider for domestic banks in the open market repo transactions. ${ }^{11}$ However, instead of providing unlimited amounts, Central Bank restricts funding amounts for individual banks. Thus, large banks such as state or private deposit banks that cannot satisfy all of their funding needs from Central Bank since they reach their borrowing limits, access to the repo market on the exchange market (BIST interbank market) and meet their uncovered funding needs from other banking groups such as foreign deposit banks with less constrained balance sheets. In particular, by the emergence of a wide interest rate spread between Central Bank average funding rate ${ }^{12}$ and BIST interbank market repo rate (see Fig. 9), foreign deposit banks borrowed from Central Bank at a cheaper rate and sold these funds to the state and private deposit banks and hence they appeared to be more active in the repo market especially in 2014 and 2015. By the end of 2015, Central Bank changed its liquidity strategy increasing the limit for the use of FX collateral in repo transactions and stopped funding via auctions in 2017. This caused a huge decrease in domestic interbank repo transactions due to the disappearance of arbitrage in the market. Overall, amendments in the local regulations implemented by Central Bank seem to affect the interbank relations in the repo market in Turkey. In repo contracts, participation banks do not create any interactions due to Sharia rules.

In derivative exposures, the concentration of transactions is among foreign deposit banks, private deposit banks, and foreign participation banks. Since foreign banks have the advantage of reaching foreign funding reserves, the network relations between these two groups of foreign banks can be predictable. However, there is another strong network among foreign and private deposit banks that may concern policy makers or central bankers. The substantial growth of derivative activities has made monetary policy design and short-term exchange rate management increasingly dependent on the interaction between domestic and foreign institutions in the derivative market. Eichengreen et al. (2011) emphasize the need to identify institutions where derivative activity is disproportionately concentrated in emerging economies. In the following section, we examine whether foreign banks have a higher coreness measure in derivative type exposures using panel data. In Turkey, foreign banks are generally medium-size, but there are also very large ones, and very small ones. Some of them operate as branches and some as participant banks. Moreover, some private domestic banks have considerable foreign shares. In Section 4.1, we examine these different types of foreign banks in a simple regression to test whether the globalization of the domestic banks and the disproportional concentration of these banks in the derivative transactions are related statistically.

In Turkey, before October 2010, only investment and development banks issued bonds; for that reason the size of the interbank bond market was small. Since Capital Markets Board has changed the regulations to allow other banks to issue bonds, the market has grown significantly and accounted for about $5.5 \%$ of total banking sector assets as of December 2017. As of the most recent data, nearly half of the banks in Turkey have issued bonds, and an important portion of these bonds is issued by state-owned and largest private deposit banks. As seen from the directions of the interactions in Fig. 8, in security type exposures, state-owned deposit banks are at the core of the network structure in terms of receiving funds. Moreover, we observe that while bonds issued by state-owned deposit banks are held by the other banks, state-owned deposit banks do not hold bonds issued by the other banks.

We argue that both liquidity risk management practices according

\footnotetext{
${ }^{11}$ CBRT has mainly two ways of funding: (i) funding via auction, in generally, one week term with a stable funding rate, and (ii) funding via quotation on the exchange market or Central Bank interbank money market on a daily term with marginal funding rate.

${ }^{12}$ Central Bank announces CBRT average funding rate since 2011.
} 


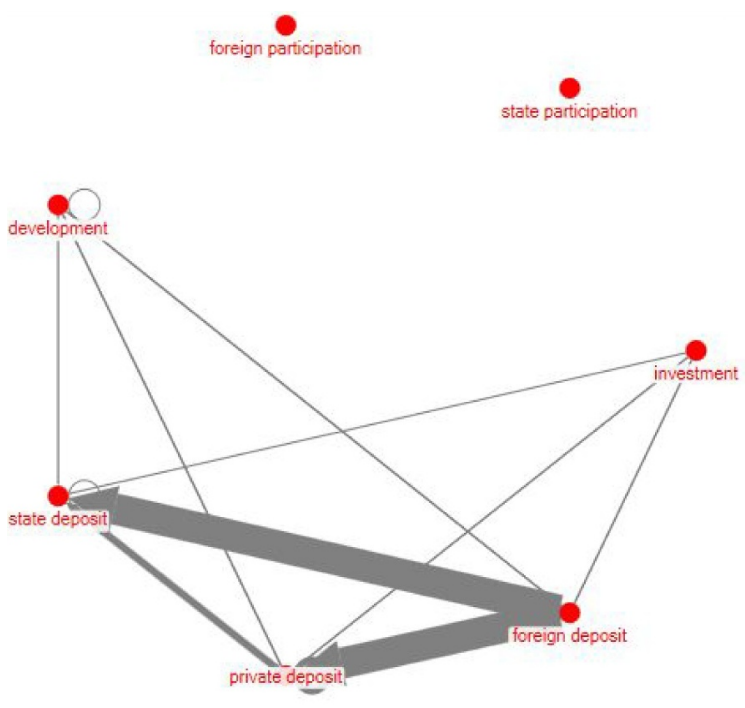

(a) Repo

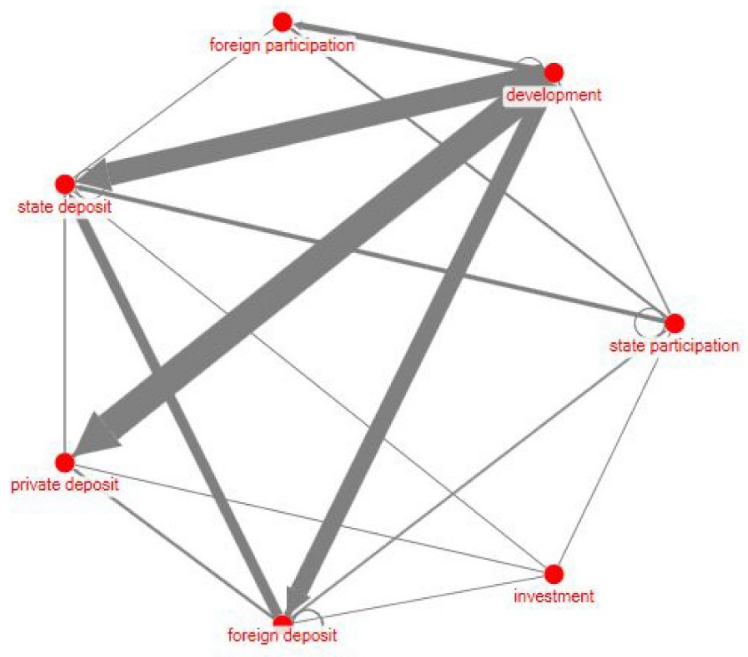

(c) Loan

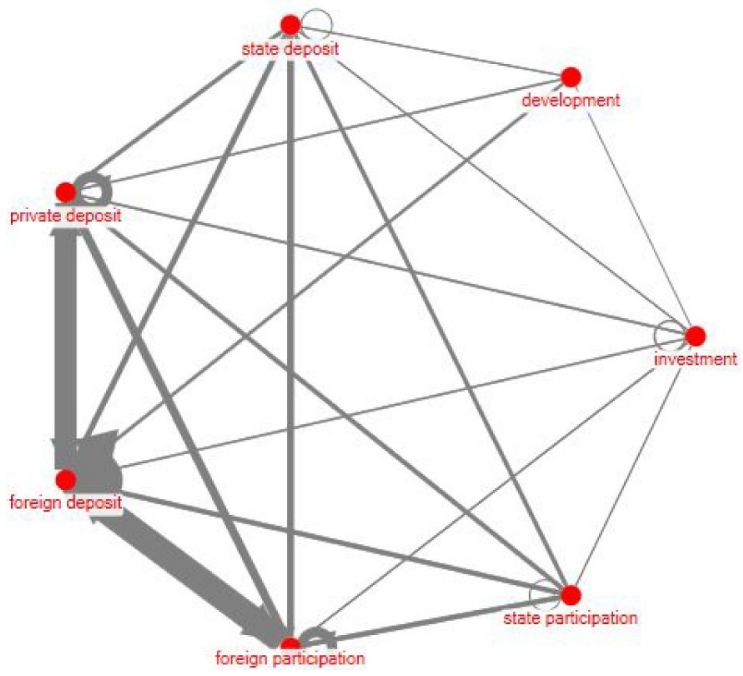

(e) Derivative

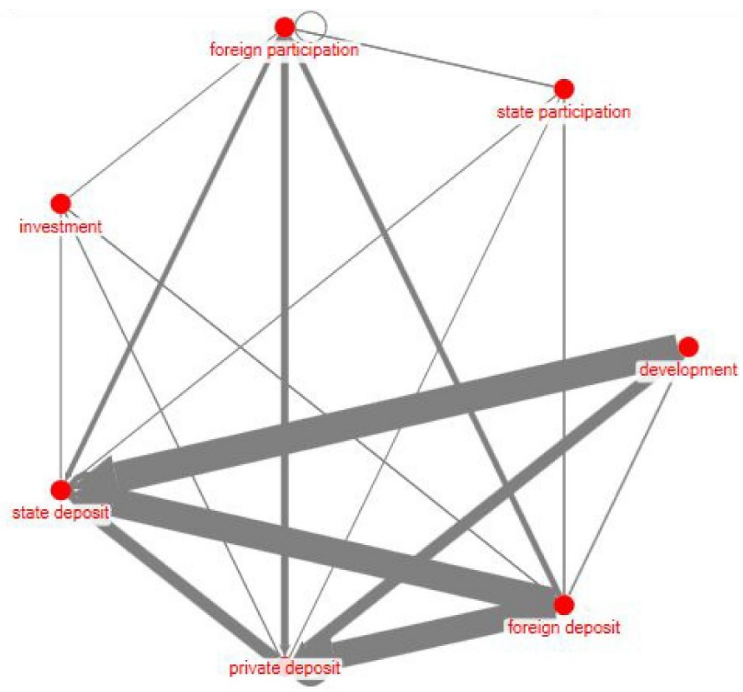

(b) Deposit

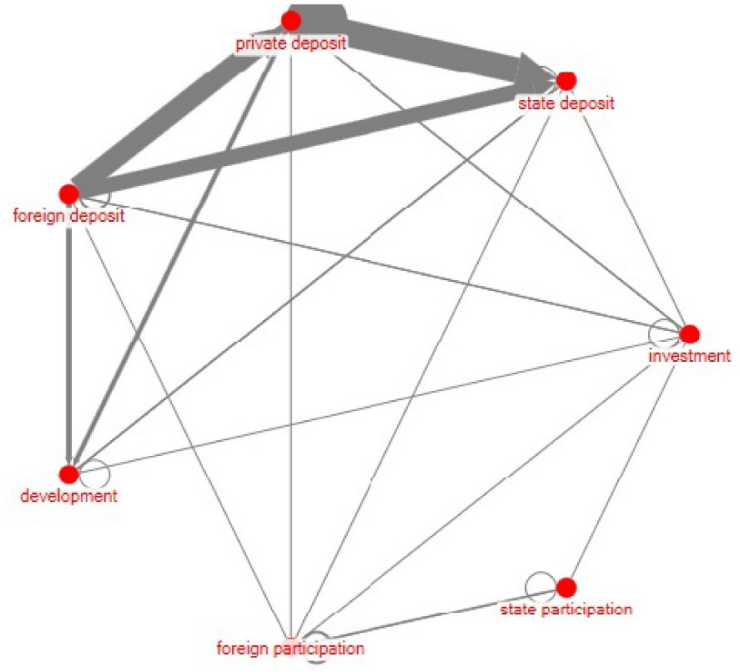

(d) Security

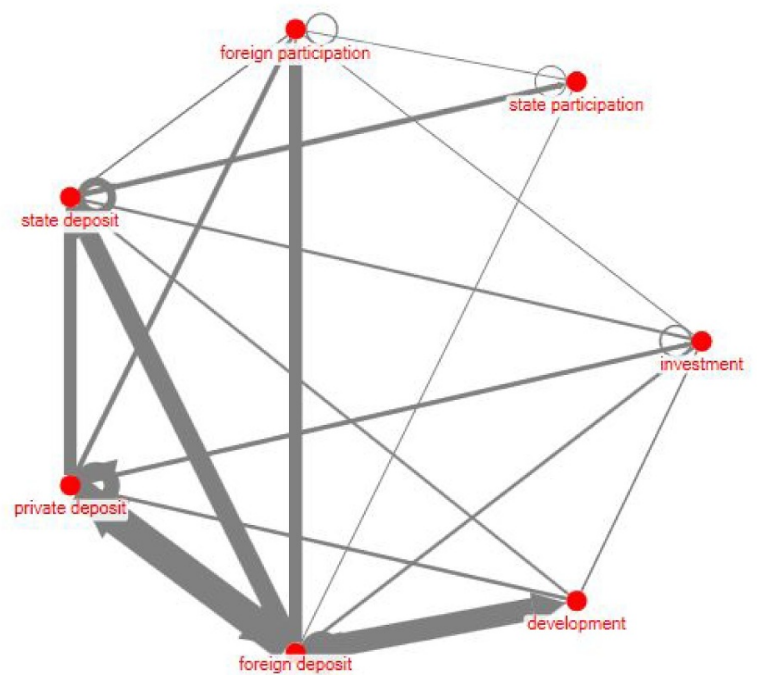

(f) Other off-balance

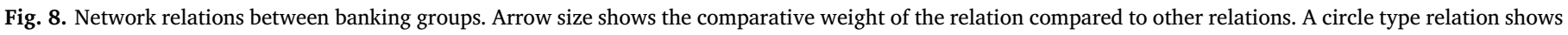
intra-group relations. 


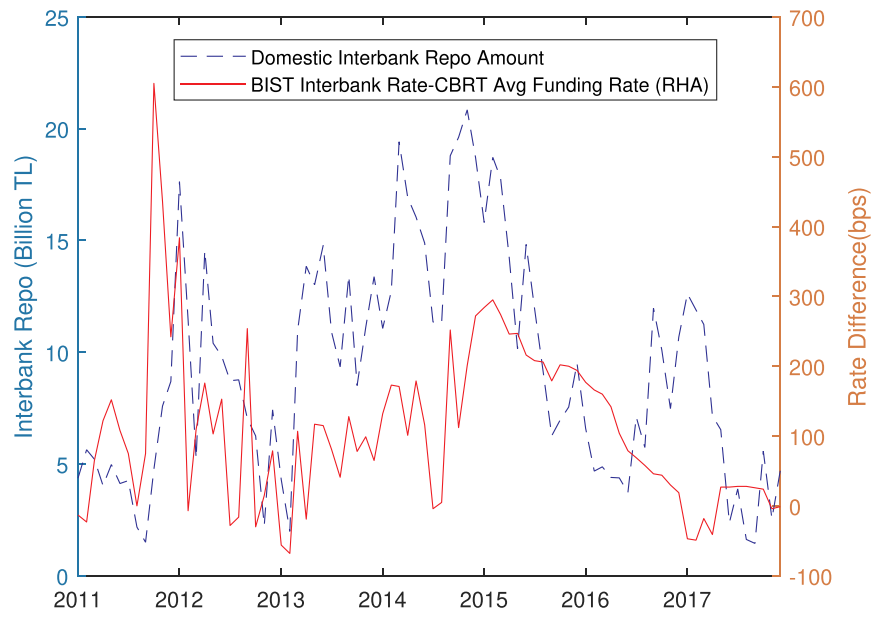

Fig. 9. Interbank repo amount and interest rate differential.

to the Basel regulations implemented after the recent financial crises and the capital adequacy framework may play a role in the shape of the network in security-type transactions (see also Bech \& Keister, 2017; Bonner \& Eijffinger, 2016). For a bank, the alternative investment to bank bond investment is government bond investment. While government bond investments are assumed as risk-free, investing in bank bonds are riskier so yields higher returns; however both investments have secondary markets, so they can be liquidated easily and may be thought of as substitute investment vehicles. However, government bonds and bank bonds are treated differently in Basel regulations and this may affect bank bond investments. Securities issued by banks are not considered as high liquid assets in the Basel liquidity coverage ratio (LCR), on the other hand government bonds are considered as high liquid assets. A bank that fails in fulfilling LCR prefers to hold government bonds instead of bank securities. However, banks with high liquidity coverage ratio or high loan-to-deposit ratio may have enough liquidity to cover any unforeseen fund requirements and prefer to invest in securities issued by other banks.

Moreover, we argue that well-capitalized banks may invest in bank bonds. While the risk weight of bonds issued by a bank depends on the rating of the bond-issuing bank, TL government bonds have zero risk weight. Bonner (2016) shows that after capital and liquidity regulations implemented, banks become more interested in goverment bonds instead of other bonds. Overall, the network structure of securities in the 2014-2017 period suggests that we should inquire further into the impact of Basel requirements on the identification of the core banks in the security network and we test our hypothesis statistically in the following section.

We observe that development banks are more active in deposit and loan interbank markets. However, when we break down the deposit and loan exposures according to local and foreign currencies, we find that, especially in the Euro transactions, foreign deposit banks are still major players in shaping the network structure. ${ }^{13}$ In the deposit exposures, about $57 \%$ of total deposit exposures belong to local currency (TL) deposits. The structure of TL and USD deposit networks is similar to the total deposit network. On the other hand, in the Euro type deposits, the importance of foreign participation banks increases and the network changes. About $35 \%$ of the loan type exposures are in local currency during our truncated sample period. Similar to the deposit contracts, the network structure between banking groups is similar in TL and USD type loans, but in Euro type loans, foreign deposit banks still have an important role in funding especially state-owned deposit banks. Finally,

\footnotetext{
${ }^{13}$ Network relations for deposit and loan exposures in currency breakdown is given in the Appendix.
}

in the other-off balance sheet items, foreign deposit banks have an important share of receivable from private deposit banks and development banks.

\subsection{Determinants of coreness measure}

In this section, we conduct several panel regressions to further understand the factors that are associated with the coreness of a bank. In the beginning of Section 4, while explaining the concentration of interbank relations between banking groups, we raise a number of questions. First, we question whether foreign banks have higher importance in derivative contracts when different foreign bank definitions are considered. Secondly, we question whether liquidity and capital requirement regulations play a role in bond investments. Therefore, after examining total interbank exposures, we focus on derivative and security type relations and inquire factors that might influence the coreness of a bank. We use coreness measures that are calculated from continuous CP structure analysis as our dependent variables. First, we study the association between total coreness in total interbank exposures during the 2003-2017 period, controlling for bank size and network statistics of a bank as in Craig and von Peter (2014). We have two size measures: the natural logarithm of total assets of a bank (Asset Size) and a dummy variable for the seven largest banks in Turkey (Large Bank Dummy). The seven banks that are referred to as the largest banks in Turkey account for almost $75 \%$ of the banking assets. We use either betweenness centrality ${ }^{14}$ (characterizes the structural role of a bank in the market) or closeness centrality ${ }^{15}$ (represents the average shortest distance in terms of links) to all the other banks in the network as our network statistics. As the explanatory variables of total coreness measure we use several bank characteristics such as CAR (capital adequacy ratio which is the regulatory capital over risk weighted assets), Liquidity Coverage Ratio (the share of high quality liquid assets over net cash outflow in the 30-day period), Loan to Deposit Ratio, and dummy variables for foreign and state banking groups. We report summary statistics and pairwise correlations of variables in Table A.1 in the Appendix.

As seen in Table 4, there is a positive and significant association between bank size indicators and the total coreness measure, supporting the previous evidence that larger banks tend to be more active in the interbank market (e.g. Cocco, Gomes, \& Martins, 2009; Craig \& von Peter, 2014). Similarly, network statistics (both betweenness and closeness centrality) are positively associated with coreness. Banks that are more central in the network either in terms of being closer to the other banks (Closeness- $T$ ) or in that they are on the intermediation path of the other nodes (Betweeness-T), have a higher coreness measure in the

\footnotetext{
${ }^{14}$ Betweenness centrality of a bank increases in relation to the importance of the bank for the money flow between banks. In other words, a bank that is between the flow path of many other banks is a central bank since the removal of that bank from the network would distort the flow that passes through it. Betweenness centrality is calculated via the following formula:

$C_{b}(i)=\sum_{s \neq t \neq i} \frac{\sigma_{s t}(i)}{\sigma_{s t}}$

where $\sigma_{s t}$ denotes the number of shortest paths going from node $s$ to $t$ and $\sigma_{s t}(i)$ is the number of shortest paths from $s$ to $t$ that pass through node $i$.

${ }^{15}$ Distance of a bank can be defined as the sum of the shortest path distance to all the banks in the network. Closeness centrality is the inverse of that total distance. For example, if a bank is directly linked to another bank, then their distance is 1 ; if they are not directly connected but there is only one bank intermediating between these banks, then their distance is 2 . Closeness centrality for bank $i$ is calculated as follows where $d$ is denoting the shortest path distance between bank $i$ and bank $j$ :
}

$C_{C}(i)=\left[\sum_{j=1}^{g} d(i, j)\right]^{-1}$ 
Table 4

Panel estimations for the determinants of total coreness measure.

\begin{tabular}{|c|c|c|c|c|c|c|}
\hline & (1) & (2) & (3) & (4) & (5) & (6) \\
\hline Asset Size (in logarithm) & $\begin{array}{l}0.0242^{* * *} \\
(0.005)\end{array}$ & & & & & \\
\hline Large Bank Dummy & & $\begin{array}{l}0.2263^{* * *} \\
(0.041)\end{array}$ & & & & \\
\hline Betweenness- $T$ & & & $\begin{array}{l}0.8098^{* * *} \\
(0.124)\end{array}$ & & & \\
\hline Closeness- $T$ & & & & $\begin{array}{l}0.2757^{* * *} \\
(0.038)\end{array}$ & & \\
\hline CAR & & & & & $\begin{array}{l}-0.4025^{* *} \\
(0.165)\end{array}$ & $\begin{array}{l}-0.3947 * * \\
(0.161)\end{array}$ \\
\hline Loan/ Deposit & & & & & & $\begin{array}{l}0.0044 \\
(0.007)\end{array}$ \\
\hline Liquidity Coverage Ratio & & & & & $\begin{array}{l}-0.0022 \\
(0.007)\end{array}$ & $\begin{array}{l}-0.0023 \\
(0.007)\end{array}$ \\
\hline Foreign Banks & & & & & $\begin{array}{l}0.0684^{* * *} \\
(0.017)\end{array}$ & $\begin{array}{l}0.0668^{* * *} \\
(0.015)\end{array}$ \\
\hline State Banks & & & & & $\begin{array}{l}0.1483^{* * *} \\
(0.035)\end{array}$ & $\begin{array}{l}0.1473^{* * *} \\
(0.035)\end{array}$ \\
\hline Constant & $\begin{array}{l}-0.3208^{* * *} \\
(0.120)\end{array}$ & $\begin{array}{l}0.1750^{* * *} \\
(0.017)\end{array}$ & $\begin{array}{l}0.1731^{* * *} \\
(0.015)\end{array}$ & $\begin{array}{l}0.0801 * * * \\
(0.018)\end{array}$ & $\begin{array}{l}0.3445^{* * *} \\
(0.046)\end{array}$ & $\begin{array}{l}0.3400^{* * *} \\
(0.043)\end{array}$ \\
\hline $\mathrm{N}$ & 8481 & 8481 & 8480 & 8480 & 1171 & 1171 \\
\hline R-squared & 0.5348 & 0.2321 & 0.4698 & 0.3964 & 0.0225 & 0.0227 \\
\hline
\end{tabular}

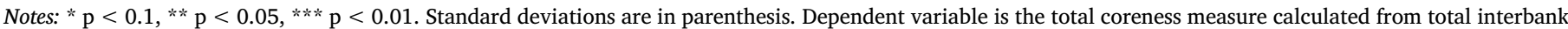

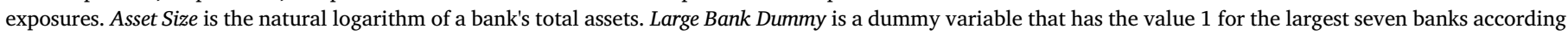

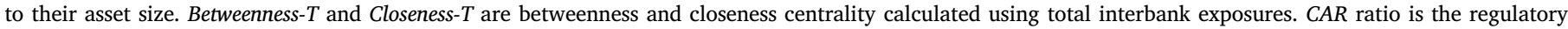

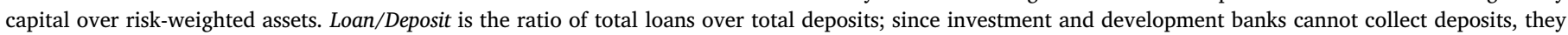

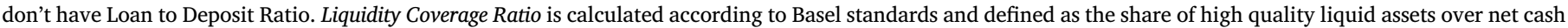

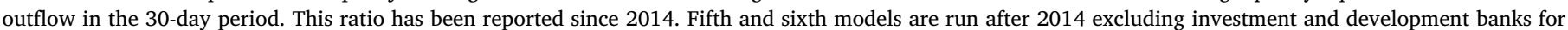

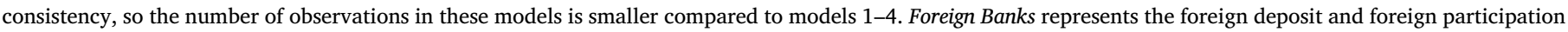

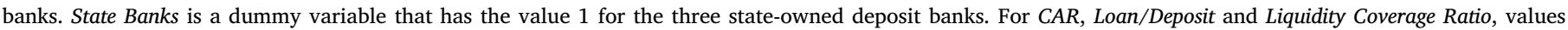
smaller than the 5 th percentile and larger than the 95th percentile are replaced by 5 th percentile and 95 th percentile values.

Turkish interbank market. Since centrality measures and coreness measures are both calculated from interbank relations, a positive relation between these variables may be expected naturally. However, while coreness measure is calculated from weighted interbank relations, centrality measures are calculated from 0-1 relations. If a bank is connected to many other banks and between the money flows of other banks, but the size of these relations is so small, then the bank will have a large centrality measure and small coreness measure. We show that this example is not the case for Turkey and the size of the interbank relations of the banks that are connected to many other banks are also large. Moreover, as seen in the fifth and sixth columns, there is a negative association between the capitalization of bank and its coreness measure suggesting that banks having a lower capital adequacy ratio are more important in the interbank market. Another interesting finding is that the liquidity of a bank has no significant association with its coreness measure. Finally, we find that state and foreign banking groups have positive and significant association with coreness measure $^{16}$

In the paper, we emphasize that each interbank contract seems to have its own network relationships among different banking groups. As we document in Fig. 8, foreign banks transact actively in most of the interbank contracts, but their importance in the derivative transactions seems to be more salient. As also seen in Fig. 10, foreign deposit banks and, very recently, foreign participation banks, have a higher than average total coreness in the derivative exposures. ${ }^{17}$ Similar to the

\footnotetext{
${ }^{16}$ As seen in Table A.1 in the appendix, asset size and other independent variables have a high correlation and for that reason we preferred not to keep asset size in models 3-6.

${ }^{17}$ The bank groups are the same as those defined in Section 2 except for foreign banks. Since some of the foreign banks are small and operate as branches only, the six largest foreign banks are selected and their average total coreness measure is calculated (they are called major foreign deposit in Figure).
}

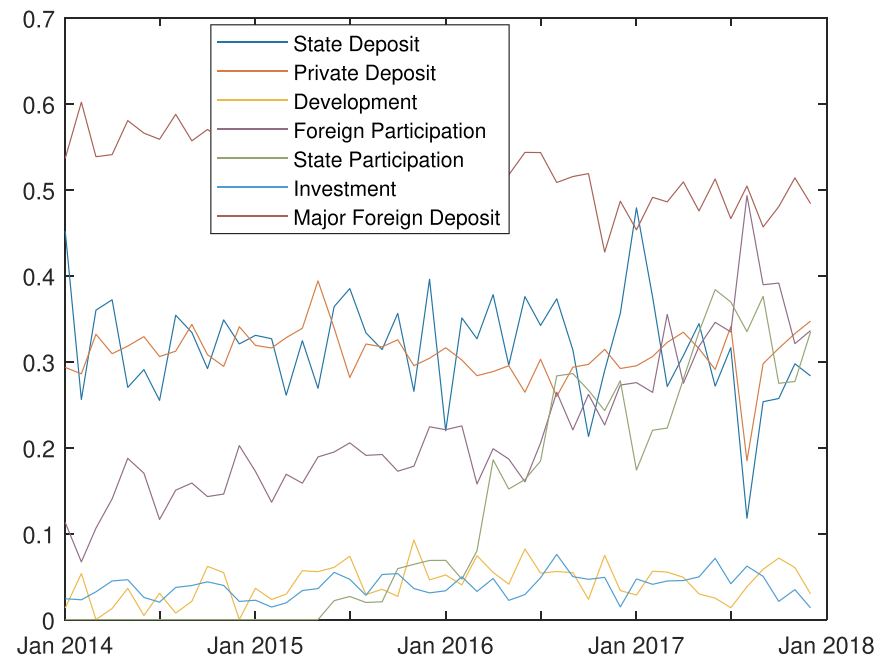

Fig. 10. Average coreness measure in derivative exposures for banking groups. Coreness measures are calculated from derivative networks and the averages of these measures are taken over the banks in the related banking group for each period.

other emerging economies, a large number of foreign banks have entered the Turkish banking system as either deposit or participation banks in the last two decades (see Table A.2 in the Appendix for detailed documentation of the foreign bank entries in Turkey during 2003-2017). In order to examine the coreness of foreign banks in the derivative markets, we estimate a simple regression model controlling for bank size and network statistics (see Table 5).

In this model, we introduce various classifications of foreign banks that may have different associations in the coreness structure. In addition to the Foreign Banks dummy variable that we use for all types of 
Table 5

Panel estimations for the determinants of derivative coreness measure.

\begin{tabular}{|c|c|c|c|c|c|}
\hline & (1) & (2) & (3) & (4) & (5) \\
\hline Asset Size & $\begin{array}{l}0.0356^{* * *} \\
(0.008)\end{array}$ & $\begin{array}{l}0.0356^{* * *} \\
(0.008)\end{array}$ & $\begin{array}{l}0.0360^{* * *} \\
(0.008)\end{array}$ & $\begin{array}{l}0.0321^{* * *} \\
(0.008)\end{array}$ & $\begin{array}{l}0.0318^{* * *} \\
(0.008)\end{array}$ \\
\hline Betweenness-D & $\begin{array}{l}0.9748^{* * *} \\
(0.254)\end{array}$ & $\begin{array}{l}0.9736^{* * *} \\
(0.254)\end{array}$ & $\begin{array}{l}0.9346^{* * *} \\
(0.254)\end{array}$ & $\begin{array}{l}0.9533^{* * *} \\
(0.250)\end{array}$ & $\begin{array}{l}0.9579 * * * \\
(0.246)\end{array}$ \\
\hline Foreign Banks & $\begin{array}{l}-0.0040 \\
(0.018)\end{array}$ & & & & \\
\hline Foreign Deposit Banks & & $\begin{array}{l}-0.0019 \\
(0.018)\end{array}$ & & & \\
\hline Major Foreign Deposit Banks & & & $\begin{array}{l}0.0535 * * \\
(0.023)\end{array}$ & & \\
\hline Major Foreign Deposit Banks25 & & & & $\begin{array}{l}0.2372^{* * *} \\
(0.045)\end{array}$ & \\
\hline Major Foreign Banks + & & & & & $\begin{array}{l}0.1902^{* * *} \\
(0.049)\end{array}$ \\
\hline Intercept & $\begin{array}{l}-0.6436^{* * *} \\
(0.177)\end{array}$ & $\begin{array}{l}-0.6448 * * * \\
(0.177)\end{array}$ & $\begin{array}{l}-0.6599 * * * \\
(0.166)\end{array}$ & $\begin{array}{l}-0.6026^{* * *} \\
(0.166)\end{array}$ & $\begin{array}{l}-0.6012^{* * *} \\
(0.174)\end{array}$ \\
\hline$N$ & 2317 & 2317 & 2317 & 2317 & 2317 \\
\hline$R$-squared & 0.6026 & 0.6030 & 0.6458 & 0.7022 & 0.6739 \\
\hline
\end{tabular}

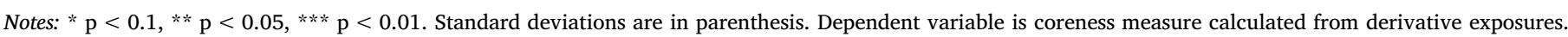

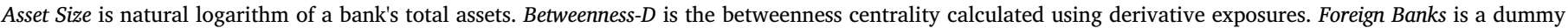

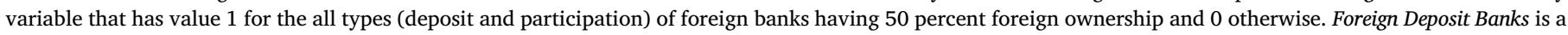

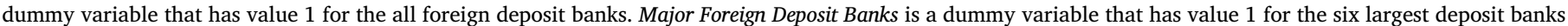

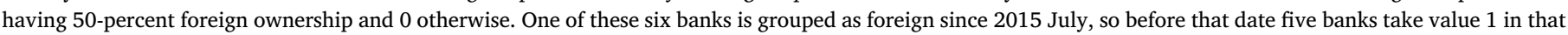

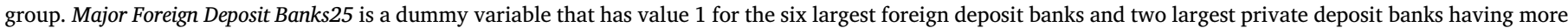

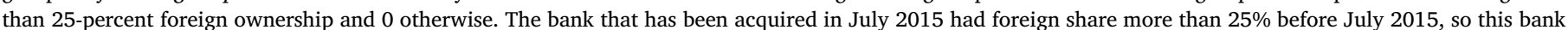

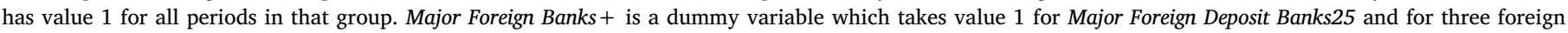
participation banks.

foreign banks (deposit and participation) in the total coreness model, ${ }^{18}$ we have four different dummy variables for foreign banks: Foreign Deposit Banks is a dummy variable to classify a subsidiary or a branch of a foreign bank but excludes foreign participation banks. Major Foreign Deposit Banks is a dummy variable that classifies large foreign deposit banks with an extensive branch network. In this subgroup, there are six banks and these banks held $84.7 \%$ of the asset share of all foreign banks as of December 2017. In the third group, we classify banks with at least $25 \%$ of foreign-owned shares as the Major Foreign Deposit Banks 25 dummy; this covers eight large foreign deposit banks. We include this classification to study how corenesss in the derivative market is affected if there are more major banks with a considerable foreign share in Turkey. As a last group, Major Foreign Banks +, we add three relatively large foreign participation banks with an extensive branch network to the third subgroup. We perform the regressions for derivative exposures using data for the 2014-2017 period due to the availability of derivative reportings.

As seen in Table 5, not all foreign banks, but rather only major foreign banks tend to be in the core. As expected, foreign banks operating with a single branch or foreign banks that are not subsidiaries of large investment banks have very small or no role in the derivative market. Nevertheless, we observe an interesting association between large foreign banks and their coreness measure in the network. When we compare the coefficients of the major foreign bank dummy variables, Major Foreign Deposit Banks and Major Foreign Deposit Banks25, we find that this association increases significantly when banks with a significant foreign share are also grouped as foreign banks. As seen in column (5), we find that with the inclusion of large foreign participation banks the association weakens, suggesting the importance of the business model of a bank in the derivative transactions.

Our last econometric exercise is related to interbank security contracts. Because banks other than investment and development banks have issued security contracts since after 2011 , we run our regressions

\footnotetext{
${ }^{18}$ For a bank to be grouped as foreign bank, either the bank should have a foreign share of more than $50 \%$, or have a foreign controlling shareholder.
}

for the period between 2011 and 2017. In this network, we have different models for security outcoreness (which shows the strength of a bank for investing in bank bonds) and security incoreness (which shows the strength of banks in terms of their bonds to be held by the other banks). In the security outcoreness model, we control for bank characteristics such as asset size, liquidity, and capitalization of a bank. Moreover, we run separate regressions for the "largest" banks and the other banks in the banking industry.

As seen in Table 6, we find that there is no association between the liquidity of a bank and security outcoreness among non-large banks. On the other hand, highly liquid (low Loan to Deposit or high Liquidity Coverage Ratio) large banks seem to invest more in bank bonds suggesting more diversification of ample resources by these banks. While the existence of significant and negative association between capitalization of a large bank and security outcoreness suggest that an increase in the capital adequacy ratio decreases the willingness to invest in bank bonds for larger banks, this effect is inverse for non-large banks. The finding for non-large banks is compatible with the expectations; however, for the large banks the relationship is contrary. Large Turkish banks have capital adequacy ratios well above minimum standards, which may be mitigating the effect on bank bond investments. On the other hand, the effect of the capital adequacy ratio is insignificant in the third and fourth model, since the estimation period is shorter in these regressions. Moreover, in the second and fourth models, the capital adequacy ratio and asset size are highly negatively correlated. If asset size is removed from the second model, the significance of the capital adequacy ratio disappears. To sum up, the findings about the effect of the capital adequacy ratio should be interpreted more cautiously.

On the other hand, for a bank to invest in another bank's bond, the bond-issuing bank must be sound. So, in order to control for the soundness of a bond-issuing bank, we use a large bank dummy, the capital adequacy ratio and the liquidity coverage ratio and present the results in column 5 and 6 of Table 6 . We find that banks invest in the bonds of large banks significantly more often. Since these banks are thought to be rescued in times of stress because they are state-owned or because they are too-big to fail, banks find that it is safer to invest in the bonds of these banks. The liquidity coverage ratio, however, has no 
Table 6

Panel estimations for determinants of security coreness measure.

\begin{tabular}{|c|c|c|c|c|c|c|}
\hline & \multicolumn{4}{|c|}{ Security outcoreness } & \multicolumn{2}{|c|}{ Security incoreness } \\
\hline & Large & Non-large & Large & Non-large & All banks & Excluding dev \& inv banks \\
\hline & (1) & (2) & (3) & (4) & (5) & (6) \\
\hline \multirow[t]{2}{*}{ Asset Size } & 0.0755 & 0.0265 & -0.0376 & 0.0416 & & \\
\hline & $(0.071)$ & $(0.023)$ & $(0.035)$ & $(0.044)$ & & \\
\hline \multirow[t]{2}{*}{ Loan/Deposit } & $-0.2964 * * *$ & 0.0082 & & & & \\
\hline & $(0.081)$ & $(0.009)$ & & & & \\
\hline \multirow[t]{2}{*}{ Liquidity Coverage Ratio } & & & $0.0553^{*}$ & 0.0144 & 0.0040 & -0.0156 \\
\hline & & & $(0.032)$ & $(0.014)$ & $(0.014)$ & $(0.011)$ \\
\hline \multirow[t]{2}{*}{ CAR } & $-2.5047^{* * *}$ & $0.0796^{*}$ & -0.1031 & -0.0240 & $-0.6573^{*}$ & -0.2931 \\
\hline & $(0.971)$ & $(0.046)$ & $(0.194)$ & $(0.114)$ & $(0.385)$ & $(0.315)$ \\
\hline \multirow[t]{2}{*}{ Large Bank Dummy } & & & & & $0.2877 * * *$ & $0.3131^{* * *}$ \\
\hline & & & & & $(0.043)$ & $(0.040)$ \\
\hline \multirow[t]{2}{*}{ Intercept } & -1.1230 & -0.5775 & 1.1381 & -0.9026 & $0.1462 * *$ & 0.0873 \\
\hline & $(1.865)$ & $(0.526)$ & $(0.953)$ & $(1.028)$ & $(0.069)$ & $(0.054)$ \\
\hline$N$ & 588 & 2232 & 336 & 982 & 826 & 720 \\
\hline$R$-squared & 0.049 & 0.025 & 0.060 & 0.006 & 0.726 & 0.812 \\
\hline
\end{tabular}

Notes: $* \mathrm{p}<0.1, * * \mathrm{p}<0.05,{ }^{* * *} \mathrm{p}<0.01$. Standard deviations are in parenthesis. In columns $1-4$, dependent variable is outcoreness measure calculated from security exposures. In columns 1 and 3, regression model is run for large banks and in columns 2 and 4, regression model is run for non-large banks. In columns 5-6, incoreness measure calculated from security exposures is used as dependent variable to understand which banks' bonds are held by other banks. These models are run for the banks issuing bonds. In column 5, all banks are considered, while in column 6 investment and development banks are excluded. Asset Size is natural logarithm of a bank's total asset. Large Bank Dummy is a dummy variable that has the value 1 for the largest seven banks according to their asset size. Liquidity Coverage Ratio is calculated according to Basel standards which is defined as the share of high quality liquid assets over net cash outflow in the 30-day period and available since 2014 . CAR ratio is the regulatory capital over risk weighted assets. Loan/Deposit ratio is total loans over total deposits ratio of the banks.For CAR, Loan/Deposit and Liquidity Coverage Ratio, values smaller than the 5th percentile and larger than the 95th percentile are replaced by 5th percentile and 95th percentile values.

significant association with the coreness measure. The capital adequacy ratio of a bank is weakly associated with the coreness measure in column 5; in other words, as the capital adequacy ratio of a bank increases the extent to invest in bonds of that bank decreases. We further examine this association by excluding development and investment banks. These banks have much higher capital adequacy ratio compared to the other banks. The average CAR ratio for the Turkish banking sector was $16.3 \%$ in the $2011-2017$ period, whereas this ratio for investment and development banks, on average, is $34.3 \%$. As seen in column 6 , the significance of the capital adequacy ratio disappears in the model without development and investment banks and, hence, we conclude that the largest banks are in the core in terms of their bonds to be held by the other banks.

\subsection{Change in banking group networks}

In this section, we examine the similarity of the network structure of banking groups through time. There are a variety of ways used in the literature to assess network similarity (Aldasoro \& Alves, 2018). While topological similarity implies similarity in terms of degree or density distributions, point-wise similarity indicates similarity in terms of the existence of links between two nodes. We analyze the time persistence in the network structures of banking groups using cosine similarity index which is a point-wise similarity measure. Cosine similarity index computes the angle between two vectors. If two vectors are the same or a multiple of each other, then cosine similarity between these two vectors (say, $X$ and $Y$ ) are $1 .{ }^{19}$ Recently, Aldasoro and Alves (2018) assessed the similarity between different instruments and maturities of large European banks using the cosine similarity index and Bargigli et al. (2015) analyzed time persistence in Italian interbank market using the same measure.

\footnotetext{
${ }^{19}$ Cosine similarity is calculated with the following formula (the ratio of dot product of two vectors over the multiples of the lengths of these vectors):

Cosine similarity index $=\frac{X Y}{\|X\|\|Y\|}$
}

In this section, we partition the total interbank exposures network according to banking groups and analyze the similarity of the banking group networks through years. In the banking group network analysis, because we focus on the last four-year average networks, we select 2013 as the base year and analyze the similarity in the networks in the last four years. We compute the cosine similarity index via comparing the network in 2013 and 2014, then 2013 and 2015 and so on. If the cosine similarity index is found to be 0.9 in 2014, this means that the similarity of the networks in 2014 compared to 2013 is $90 \%$, so the network changed $10 \%$ in one year. As seen in Fig. 11a, we observe that networks of foreign participation banks, investment banks, and stateowned banks change more than the other banking groups in the four year period from 2013 to 2017 . We find that the network of stateowned banks, foreign participation, investment banks change by 9,66 , and $15 \%$ respectively since cosine similarity index in 2017 is 91,34 , and $85 \%$ for these banking groups. Since there was no state-owned participation banks in 2013, we do not see this group in the figures.

We also report cosine similarity measures for each banking group, excluding derivative exposures, in Fig. 11b. Since derivative instruments were started to be reported in 2014, their entry might have some impact on the similarity measure. As seen in Fig. $11 \mathrm{~b}$, cosine similarity index for foreign participation banks decreases to $83 \%$ in 2017 from 100 -percent level in 2013, so when derivative exposures are excluded, the change in the network in the four year becomes $17 \%$. If we compare the change in the network of foreign participation banks in Fig. 11a and $\mathrm{b}$, we see that the change in the network of foreign participation banks decreases significantly, from $66 \%$ to $17 \%$ when derivative instruments are excluded. As presented in Section 4.1, foreign participation banks have an important role in derivative transactions and exclusion of these transactions changes the network among banking groups significantly. Nevertheless, we find that the highest change in the network is still among foreign participation banks (17\%) and state-owned banks (8\%).

Since 2015, two new state participation banks have entered the Turkish banking system, one of which started to operate in May 2015 and the other in February 2016. Since these newly entered state-owned participation banks are subsidiaries of state deposit banks and they work according to the same principles as the other participation banks, the change in the network structure of state and participation banks 


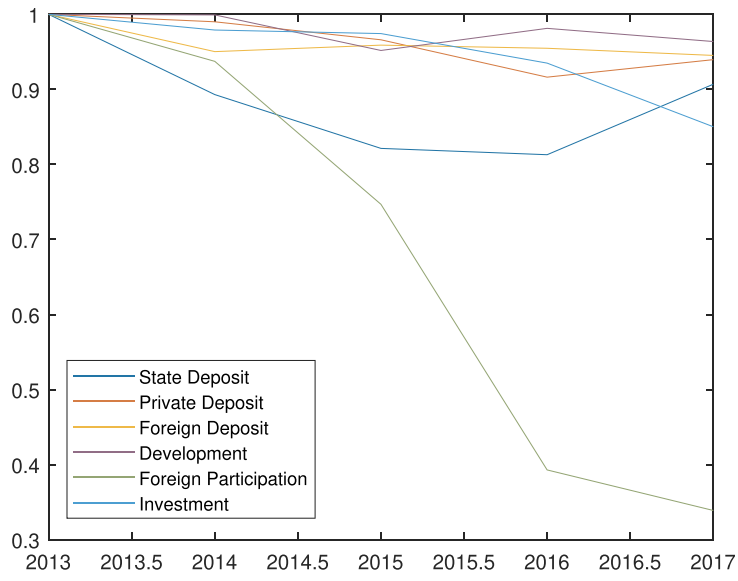

(a) Total Exposures

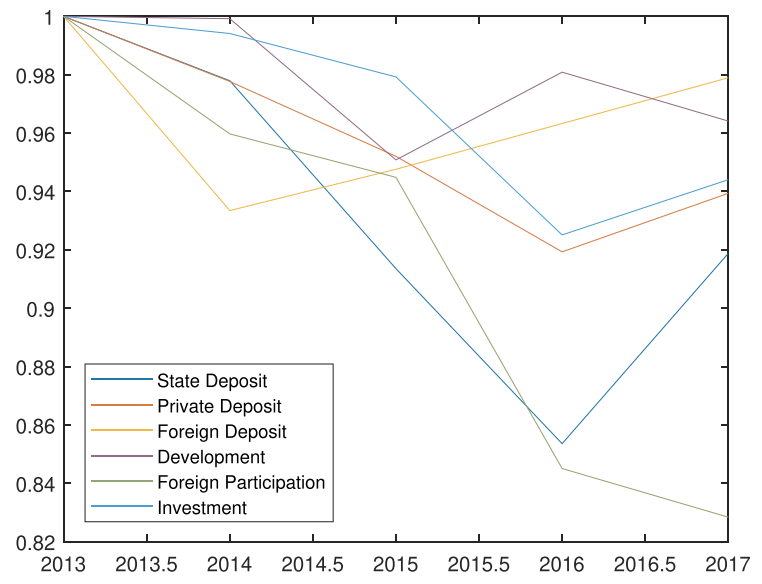

(b) Total Exposures Excluding Derivatives

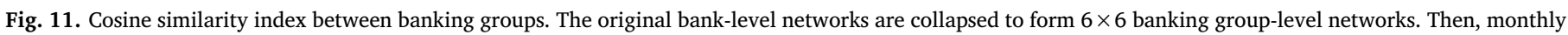

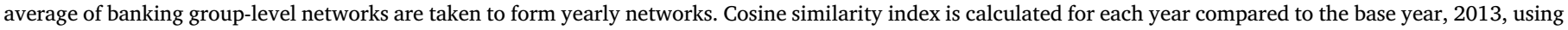
banking group-level networks.

after 2015 might be due to these new entries. Moreover, one private participation bank grouped under foreign participation banks exited in 2016. When we examine the change in the network structure between 2013 and 2014 from Fig. 11a, where the effect of new bank entries and bank exits are absent, we again see that the networks of state and foreign participation banks have changed more than other banks. ${ }^{20}$

\subsection{Effect of foreign bank acquisitions on network structure}

In this section, we examine the change in network structure after foreign bank acquisitions in Turkey. During the sample period, there were 22 foreign acquisition observations belonging to 17 banks in Turkey (see Table A.2 in the Appendix). ${ }^{21}$ Since after a foreign acquisition, governance of the acquired domestic bank would change, we hypothesize that a foreign acquisition may have an effect on the network structure of the acquired bank. As explained in the previous section, cosine similarity index is a good measure to analyze the similarity between different networks and assess whether network structure changed after the acquisitions. To calculate the cosine similarity index, if foreign acquisition is in year $t$, we compare the network of the bank in year $t-1$ and $t+1$. In our analysis, we exclude security issuances and derivatives due to late existence of these transactions in the interbank relations. New bank entries, exits or mergers may also have an effect on the network change, so we examine network relations between 42 banks that are all active in the analysis period. We compare the change in the network of the acquired bank with the change in the network of the other banks. In this way, we are able to infer whether foreign acquisitions have a significant effect on the network relations of the acquired bank.

Table 7 summarizes cosine similarity index values for the acquired banks and remaining other banks. For example, in 2005 two banks were acquired by foreigners. When we compare the networks of these banks

\footnotetext{
${ }^{20}$ As a robustness check, change in network structure is analyzed only considering the banks that have been active in the whole period between 2013 and 2017. So, 5 banks ( 3 exits and 2 entries) are excluded from the network and the analysis is repeated. When these banks are excluded the change in the network of state-owned banks decreased a little (from 8\% to 7\%) and foreign participation banks increased a little (from $17 \%$ to $18 \%$ ) but the decrease is not so significant.

${ }^{21}$ We only focus on significant foreign acquisitions here and share acquisitions in smaller percentages via investment funds are not included.
}

Table 7

Cosine similarity index of the networks before and after foreign acquisitions.

\begin{tabular}{llll}
\hline \multirow{2}{*}{ Year of foreign } & Number of & \multicolumn{2}{l}{ Cosine similarity index of } \\
\cline { 3 - 4 } acquisition & acquisitions & Banks purchased by foreigners & Other banks \\
\hline 2005 & 2 & $0.680 ; 0.331$ & 0.781 \\
2006 & 4 & $0.249 ; 0.171 ; 0.513 ; 1.000$ & 0.657 \\
2007 & 5 & $0.246 ; 0.846 ; 0.709 ; 0.662 ; 0.344$ & 0.790 \\
2008 & 1 & 0.764 & 0.748 \\
2009 & 0 & - & - \\
2010 & 1 & 0.191 & 0.468 \\
2011 & 2 & $0.674 ; 0.753$ & 0.432 \\
2012 & 2 & $0.666 ; 0.601$ & 0.670 \\
2013 & 1 & 0.846 & 0.658 \\
2014 & 0 & - & - \\
2015 & 3 & $0.776 ; 0.696 ; 0.346$ & 0.490 \\
2016 & 1 & 0.635 & 0.610 \\
\hline
\end{tabular}

Notes: The table shows the cosine similarity index of the networks calculated via comparing the networks before and after foreign acquisitions. The first column shows the year of foreign acquisition and second column shows the number of bank acquisitions in that year. When calculating the cosine similarity index, if foreign acquisition is in year $t$, we compare the network in year $t-1$ and $t+1$ and report the similarity index in third and fourth columns. Third column shows the cosine similarity index for the banks acquired by foreigners and calculated for the $1 \mathrm{x} n$ network of the acquired bank where $n$ shows the total number of banks. Cosine similarity index of each bank acquired in the related year is seperated with semi-colons in the third column. Fourth column shows the cosine similarity index for the other banks that are not acquired by a foreigner in that year and calculated for the $(n-a) \mathrm{x}(n-a)$ network of the other banks where $a$ shows the number of acquired banks in that year. Numbers in italic indicate the violating observations of the hypothesis that foreign acquisitions change the network structure of the acquired bank more compared to the network structure of the other banks. If the cosine similarity index in the third column is higher than the number in the fourth column, this means that the network of the bank acquired by a foreign bank changed less after the foreign acquisition compared to the network of other banks, so this observation violates the hypothesis.

in years 2004 and 2006, we find that cosine similarity index is 0.680 and 0.331 respectively suggesting that the networks of the banks changed by $34 \%$ and $66.9 \% .{ }^{22}$ On the other hand, cosine similarity

\footnotetext{
${ }^{22}$ The change in the network between two years is calculated as the difference of cosine similarity index from one.
} 
index for the network composed of all remaining active banks is 0.781 suggesting the change in the network is $21.9 \%$. Thus, in 2005 , the networks of the two acquired banks changed more compared to the network of other banks. In Table 7, the numbers in italic report the cases that violate our hypothesis, i.e., a foreign bank acquisition did not affect the network of the acquired bank. For example, in 2006, we find that one out of four acquisitions violates our hypothesis since cosine similarity index of that bank is higher than the cosine similarity index value of the banks other than the acquired banks.

Overall, cosine similarity index values suggest that foreign acquisitions seem to change the network in Turkey. In particular, while before 2010, of 13 foreign acquisitions, for ten of them change in the network of the bank whose shares are acquired is higher as compared to the change in the network of the other banks. After 2010, there are evidence that network structure has changed for some banks by the foreign bank acquisitions but not as common as before. An acquisition wave has swept through Turkish banking system during 2005-2010 with foreigners being the controlling shareholders of the acquired banks. On the other hand, nearly half of the violating observations (of the hypothesis that foreign acquisitions change network structure) after 2010 belong to the second acquisitions of the banks that were previously acquired by foreign banks (see Table A.2 in the Appendix). Thus, we argue that one should not expect to see the network structure to change as significant as before since another foreign bank takeover wouldn't have a significant change on the network structure of the acquired foreign bank.

As we mentioned before, we exclude derivative contracts in the analysis of foreign acquisitions due to their short existence in the interbank transactions. However, we have also shown that foreign banks have an important role in the derivative contracts. We expect that if we have the chance to study the change in the network including derivative contracts, we could have observed stronger evidence of change in the networks of acquired banks. So, we suggest that this hypothesis is worthy of being tested in the networks of other countries.

\section{Conclusion}

In this paper, using monthly interbank exposures data, we examine the interbank network structure and association among different banking groups in a large emerging economy. Our findings show that the core-periphery (CP) structure gives a better fit to the Turkish interbank network compared to the random and scale-free structures. This finding suggests that banks in Turkey care counterparty relationships and link formations in the interbank market during the sample period of 2003-2017. In a banking system with no regional banks, we find all large banks, some medium-sized banks, and even small banks to be highly connected. The existence of small banks in the core bank set is very interesting, considering their role in funding SMEs in an emerging economy. Nevertheless, the asset size and network statistic of a bank, (i.e., betweenness or closeness centrality) are found to be the major determinants of the coreness of a bank.

Although the probability of an event large enough to distress a larger institution is low, if a large enough shock were to occur, it may disrupt the whole payment system. Turkey had a similar experience almost two decades ago. In November 2000, banks started to close their interbank credit lines to vulnerable Turkish banks after concerns about the health of the banking sector. Consequently, the difficulties of large state-owned deposit banks and mid- and small-sized private deposit banks turned into a systemic banking crisis in February 2001. Since then, a new regulatory system and the financial liberalization of the market have deepened the financial system in Turkey. Hence, we argue that monitoring the coreness of a bank as well as its interactions with other banks provides valuable information on the stability of the whole banking system and the real economy.

In our analysis we study, for the first time, the interbank network structure using banking group and instrument breakdown and find that some banking groups, especially foreign and state deposit banks, play an important role in shaping the interbank network structure. Using the cosine similarity measure, we observe that foreign bank entries, especially before 2010, seem to change the Turkish interbank network structure. Among 22 events of foreign acquisitions during the sample period, we show how the entrance of a foreign bank or an increase in the shareholding of a foreign partner changes the network structure of the acquired/target bank. The tiered or CP structure of the interbank system arises partly for organic reasons and partly in response to regulatory constraints. In the paper, as a final contribution, we also show that some local factors, such as the limits in the repo market with the Central Bank and Basel regulations, play a role in shaping the network structure. In particular, highly liquid large banks and well-capitalized non-large banks are found to invest more in the interbank security market.

This study is important in terms of several policy implications. Foreign bank interest in domestic banks is important for the financial and economic development of the emerging countries. On the other hand, foreign banks have comparative advantage in some type of instruments such as derivatives which generally have a shorter maturity and more complex structure compared to other instruments. Considering the growing derivative transactions in a financially integrated emerging economy such as Turkey, the coreness of foreign banks has to be also monitored for the stability of the currency markets. Moreover, the acquisition of domestic banks via foreign banks changes the network structure of the acquired bank if the share purchases are in higher percentages.

Additionally, among banking groups, we present evidence that state banks tend to invest in other state institutions and hence increase the concentration of risks. The regulatory authorities should follow risk concentrations in the network for the stability of the interbank markets. 


\section{Appendix A. Core-periphery model and estimation approach}

Discrete core-periphery (CP) models aim to classify nodes as either core or periphery via working with adjacency matrices, alternatively in continuous models, a coreness measure is assigned to each node. If the values of coreness measures are restricted to take binary values, then continuous model reduces to the discrete model. Borgatti and Everett (2000) which is the first study that defines CP structure formally, impose two conditions for a perfect discrete CP model. The first condition is that core banks should be bilaterally linked to each other and the second condition is that periphery banks should not have any link with each other. On the other hand, they do not impose any restriction for core to periphery and periphery to core relations. Craig and von Peter (2014) modify this model to be used for interbank relations via adding the third condition which imposes that core banks should both lend to and borrow from at least one periphery bank.

To be able to compare the fitness of different core-periphery partitions, alternative fitness measures are used in the literature. While Borgatti and Everett (2000) use the unnormalized Pearson correlation coefficient, Craig and von Peter (2014) use error score as the fitness measure. In Craig and von Peter (2014) approach, any missing or extra link in the network that does not satisfy the above-mentioned three conditions are both counted as an error. For example, in the ideal CP structure there should not be any link between periphery banks, if there were any link between the identified periphery set then they would all be counted as an error. Similarly, since all banks in the core set should be connected to each other, any missing link between these banks is counted as an error. The aim of the problem is to find the core-periphery partition which minimizes the total number of error scores.

The use of exhaustive search algorithms for fitting deterministic models and grouping banks as core and periphery becomes inefficient as the size of nodes increase. Therefore, generally heuristic approaches are preferred to solve the problem in the literature. As the heuristic approach, we use Craig and von Peter (2014) sequential optimization algorithm. In that algorithm, first square root of the number of banks in the system are selected randomly and assigned as core banks. Then, the error score of this random assignment is calculated. Over all the nodes, we search for the node that will give highest decrease in error score if core-periphery assignment of this node is reversed. The assignment of this node is reversed and this step is repeated until there is no need for a change. To avoid running in local optimum, the steps starting with the random core assignment is repeated for 1000 times. At the end of the algorithm, the nodes that have been found as core banks in at least $80 \%$ of the steps are selected as core banks and the remaining banks are assigned as periphery banks.

In the estimation approach for continuous $\mathrm{CP}$ model, the aim is to minimize the sum of squared differences between pattern matrix implied by coreness measures of the nodes and weighted actual matrix where $\omega$ and $p$ denote weighted actual matrix and pattern matrix respectively. This problem is formulated mathematically as follows:

$\arg \min _{c} \sum_{i} \sum_{j \neq i}\left(\omega_{i j}-p_{i j}\right)^{2}$

There are two versions of continous $\mathrm{CP}$ model depending on the definition of the pattern matrix. In the symmetric version of $\mathrm{CP}$ model, there is only one coreness vector, $c$, where $0 \leq c_{i} \leq 1$ and $p=c c^{\prime}$ (Borgatti \& Everett, 2000). If the amount borrowed by a bank differs significantly from the amount lent by this bank, then the use of two coreness measures, $u$ and $v$ to represent outcoreness and incoreness vectors is suggested in the asymmetric version of CP model and $p=u v^{\prime}$ (Boyd et al., 2010). Outcoreness vector shows the importance of the bank in terms of lending to the other banks and incoreness vector shows the importance of the banks in terms of borrowing from the other banks. 


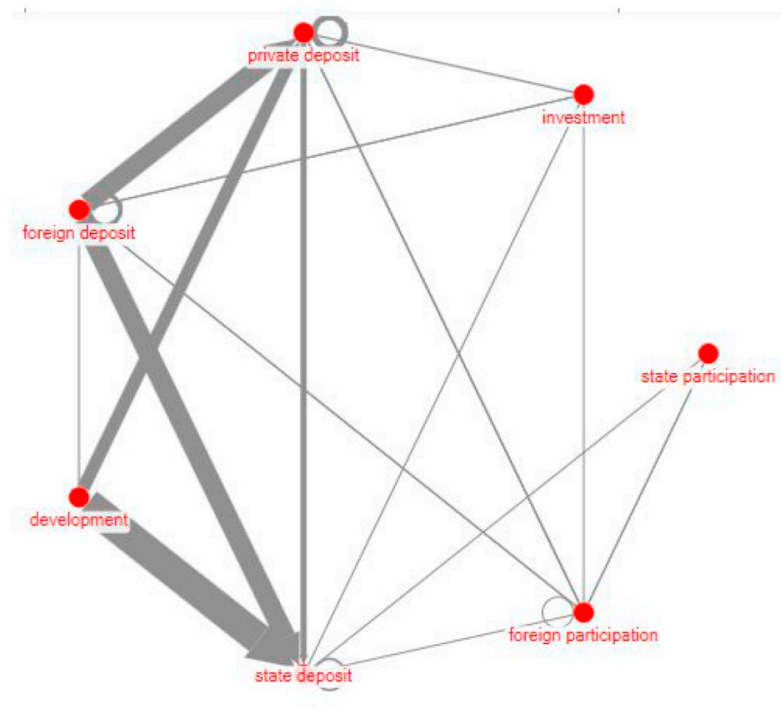

(a) TL deposit

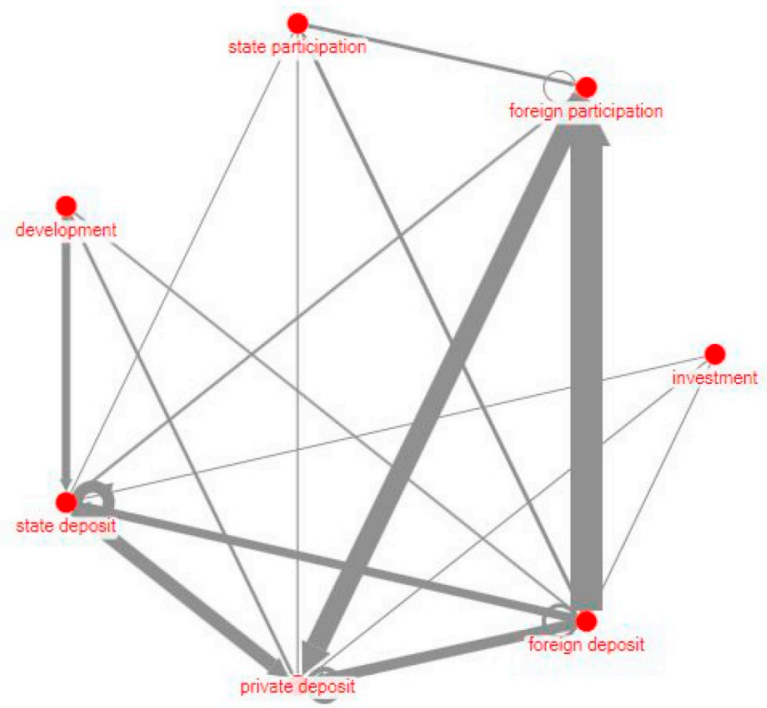

(c) EUR deposit

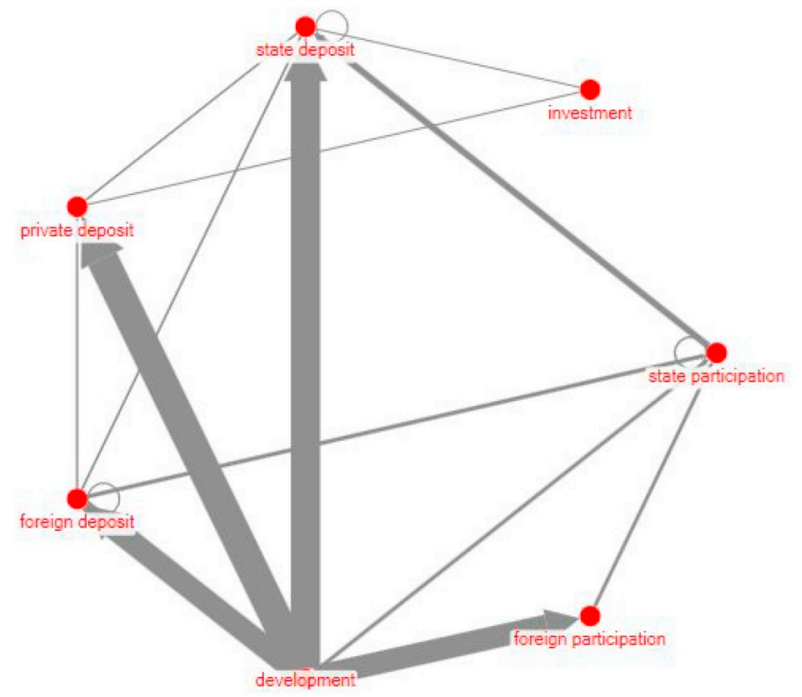

(e) USD loan

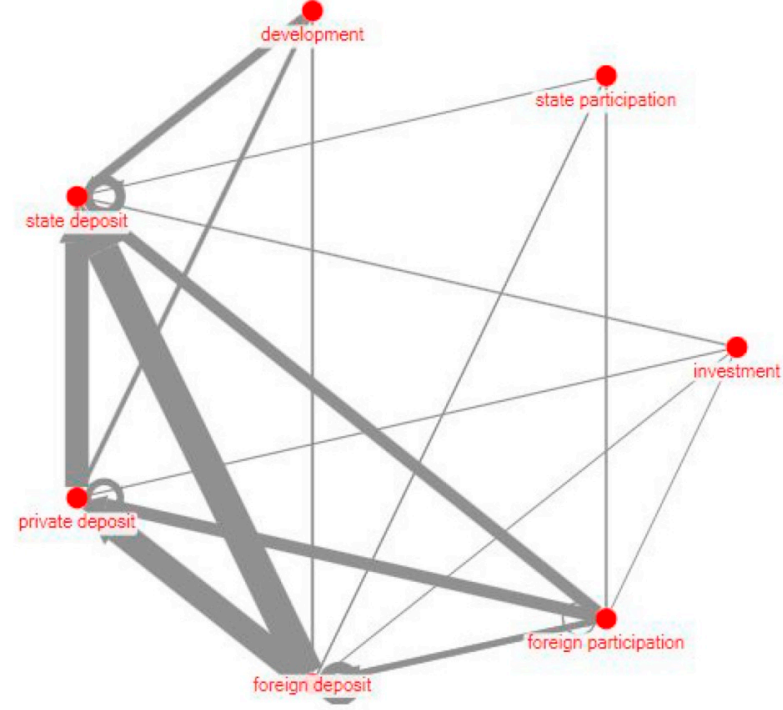

(b) USD deposit

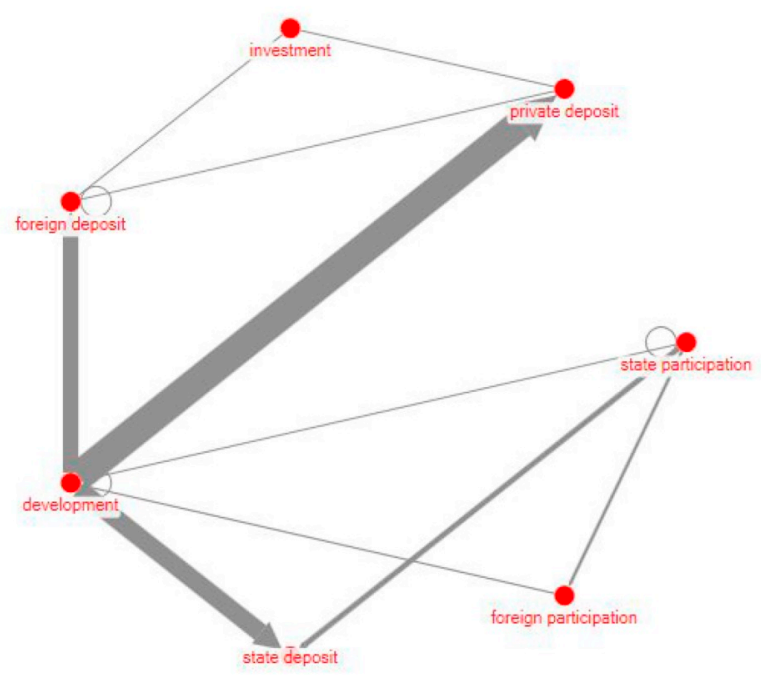

(d) TL loan

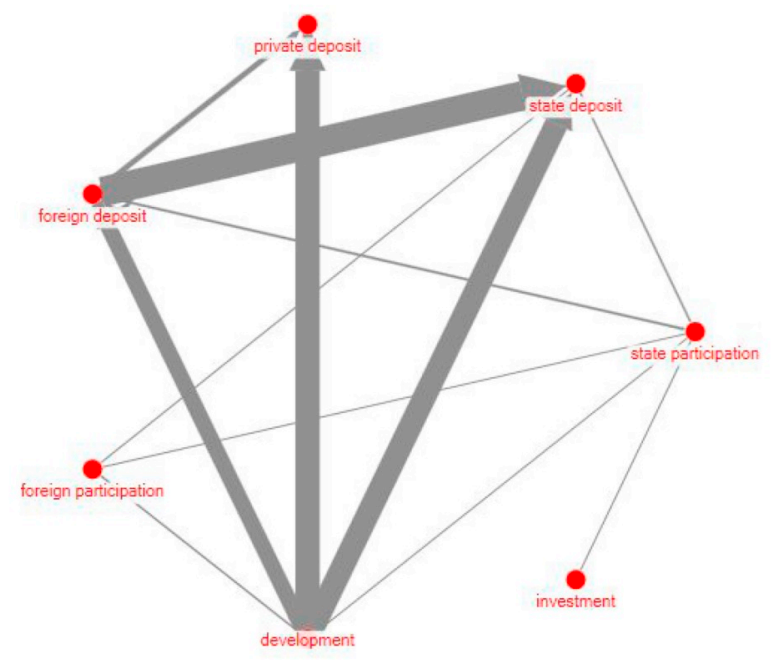

(f) EUR loan 


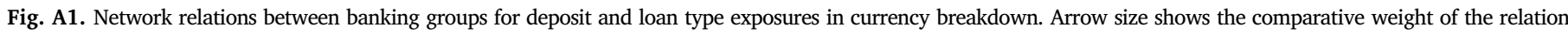
compared to other relations. A circle type relation shows intra-group relations.

Table A.1

Descriptive statistics and correlations.

\begin{tabular}{|c|c|c|c|c|c|c|c|c|}
\hline & (1) & (2) & (3) & (4) & (5) & (6) & (7) & (8) \\
\hline \multicolumn{9}{|l|}{ Descriptive statistics: } \\
\hline Mean & 21.857 & 0.149 & 0.041 & 0.475 & 0.019 & 1.209 & 1.290 & 0.340 \\
\hline Standard deviation & 2.411 & 0.356 & 0.077 & 0.162 & 0.066 & 1.253 & 0.660 & 0.291 \\
\hline $\mathrm{N}$ & 8481 & 8481 & 8480 & 8480 & 2317 & 4832 & 1318 & 8348 \\
\hline \multicolumn{9}{|l|}{ Pairwise correlation: } \\
\hline (1) Asset Size (in logarithm) & 1 & & & & & & & \\
\hline (2) Large Bank Dummy & 0.582 & 1 & & & & & & \\
\hline (3) Betweenness-T & 0.437 & 0.500 & 1 & & & & & \\
\hline (4) Closeness- $T$ & 0.578 & 0.206 & 0.408 & 1 & & & & \\
\hline (5) Betweenness-D & 0.331 & 0.420 & 0.887 & 0.417 & 1 & & & \\
\hline (6) Loan/Deposit & -0.247 & -0.154 & -0.132 & -0.125 & -0.125 & 1 & & \\
\hline (7) Liquidity Coverage Ratio & -0.315 & -0.194 & -0.130 & -0.205 & -0.029 & -0.070 & 1 & \\
\hline (8) $C A R$ & -0.545 & -0.187 & -0.278 & -0.411 & -0.136 & 0.087 & 0.442 & 1 \\
\hline
\end{tabular}

Table A.2

Foreign purchases of Turkish banks.

\begin{tabular}{|c|c|c|c|c|c|}
\hline & Purchase date & Target bank & Purchaser & Percent share & New name \\
\hline $1 *$ & February 2005 & TEB Holding & BNP Paribas & 41.25 & \\
\hline $2^{\dagger}$ & September 2005 & $\mathrm{YKB}$ & Koç Holding (50\% Unicredit Bank) & 57.43 & \\
\hline 3 & August 2006 & Finansbank & National Bank of Greece & 46.00 & \\
\hline 4 & October 2006 & Denizbank & Dexia & 75.00 & \\
\hline 5 & November 2006 & C Bank & Bank Hapoalim & 57.55 & Bank Pozitif \\
\hline 6 & December 2006 & Tatbank & Merrill Lynch & 100.00 & Merrill Lynch \\
\hline 7 & January 2007 & Akbank & Citibank & 20.00 & \\
\hline 8 & January 2007 & MNG Bank & Arab Bank PLC (50\%) + Bank Med(41\%) & 91.00 & Turkland Bank \\
\hline 9 & March 2007 & Şekerbank & Bank Turanalem JSC & 33.89 & \\
\hline 10 & March 2007 & Tekfenbank & EFG Eurobank & 70.00 & Eurobank Tekfen \\
\hline 11 & February 2008 & Turkishbank & National Bank of Kuwait & 40.00 & \\
\hline 12 & February 2008 & Oyakbank & ING Bank & 100 & ING Bank \\
\hline 13 & December 2010 & Millenium Bank & Credit Europe Bank NV & 95.00 & Fibabanka \\
\hline $14^{*}$ & February 2011 & Fortisbank & Türk Ekonomi Bankası & 100.00 & Türk Ekonomi Bankası \\
\hline 15 & March 2011 & Garanti Bankası & BBVA & 24.89 & \\
\hline 16 & September 2012 & Denizbank & Sberbank of Russia & 99.8 & \\
\hline 17 & December 2012 & Eurobank Tekfen & Burgan Bank & 99.26 & Burgan Bank \\
\hline 18 & July 2013 & Alternatifbank & Commercial Bank of Qatar & 74.30 & \\
\hline 19 & February 2015 & Taibbank & Pasha Bank OJSC & 79.90 & Pasha Bank \\
\hline 20 & May 2015 & Tekstil Bankası & Industrial and Commercial Bank of China (ICBC) & 75.50 & ICBC Turkey \\
\hline 21 & June 2016 & Finansbank & Qatar National Bank & 99.80 & \\
\hline 22 & July 2015 & Garanti Bankası & BBVA & 14.89 & \\
\hline
\end{tabular}

Notes: Purchase dates show the effective change in shareholder structure. "BNP Paribas has bought $50 \%$ of TEB Holding, so indirect shareholding of BNP Paribas in Türk Ekonomi Bankası became 41.25\%. ${ }^{\dagger} 57.43 \%$ of YKB was purchased by Koç Holding in which Unicredit has 50-percent shares, so indirect shares of Unicredit in YKB became 28.7\%. *After that acquisition, foreign share in Türk Ekonomi Bankası became 68\%.

\section{References}

Acemoglu, D., Ozdaglar, A., \& Tahbaz-Salehi, A. (2015). Systemic risk and stability in financial networks. American Economic Review, 105(2), 564-608.

Akyüz, Y., \& Boratav, K. (2003). The making of the Turkish financial crisis. World Development, 31(9), 1549-1566.

Aldasoro, I., \& Alves, I. (2018). Multiplex interbank networks and systemic importance: An application to European data. Journal of Financial Stability, 35, 17-37.

Allen, F., \& Babus, A. (2009). Networks in finance. The network challenge: Strategy, profit, and risk in an interlinked world (pp. p. 367). .

Allen, F., Carletti, E., \& Gale, D. (2009). Interbank market liquidity and central bank intervention. Journal of Monetary Economics, 56(5), 639-652.

Allen, F., \& Gale, D. (2000). Financial contagion. Journal of Political Economy, 108(1), $1-33$.

Barabasi, A. L., \& Albert, R. (1999). Emergence of scaling in random networks. Science, 286(5439), 509-512.

Bargigli, L., Di Iasio, G., Infante, L., Lillo, F., \& Pierobon, F. (2015). The multiplex structure of interbank networks. Quantitative Finance, 15(4), 673-691.

Bech, M., \& Keister, T. (2017). Liquidity regulation and the implementation of monetary policy. Journal of Monetary Economics, 92, 64-77.

Bonner, C. (2016). Preferential regulatory treatment and banks' demand for government bonds. Journal of Money, Credit and Banking, 48(6), 1195-1221.

Bonner, C., \& Eijffinger, S. C. (2016). The impact of liquidity regulation on bank intermediation. Review of Finance, 20(5), 1945-1979.

Borgatti, S. P., \& Everett, M. G. (2000). Models of core-periphery structures. Social Networks, 21, 375-395.

Boyd, J. P., Fitzgerald, W. J., Mahutga, M. C., \& Smith, D. A. (2010). Computing continuous core/periphery structures for social relations data with MINRES/SVD. Social Networks, 32, 125-137.

Calomiris, C. (2011). The AAF virtual debates: Charles calomiris on State-Owned banks. World Bankhttp://blogs.worldbank.org/allaboutfinance/the-aaf-virtual-debatescharles-calomiriss-response-on-state-owned-banks (02 Feb. 2011).

Cocco, J. F., Gomes, F. J., \& Martins, N. C. (2009). Lending relationships in the interbank market. Journal of Financial Intermediation, 18(1), 24-48.

Cont, R., Moussa, A., \& Santos, E. (2013). Network structure and systemic risk in banking systems. In J. Fouque, \& J. Langsam (Eds.). Handbook on systemic risk (pp. 327-368). Cambridge: Cambridge University Press.

Craig, B., \& von Peter, G. (2014). Interbank tiering and money center banks. Journal of Financial Intermediation, 23(3), 322-347.

Degryse, H., \& Nguyen, G. (2007). Interbank exposures: An empirical examination of systemic risk in the Belgian banking system. International Journal of Central Banking, 3(2), 123-171.

Dornbusch, R. (2001). A primer on emerging market crises. ManuscriptMIT, Department of 
Economics.

Eichengreen, B., et al. (2011). Rethinking central banking. Committee on International Economic Policy and Reform. Washington, D.C.: Brookings.

Erdös, P., \& Renyi, A. (1959). On random graphs, I. Publicationes Mathematicae, 6, 290-297.

Freixas, X., Parigi, B. M., \& Rochet, J. C. (2000). Systemic risk, interbank relations, and liquidity provision by the central bank. Journal of Money, Credit and Banking, 32(3), 611-638.

Fricke, D., \& Lux, T. (2015). Core-periphery structure in the overnight money market: Evidence from the e-mid trading platform. Computational Economics, 45(3), 359-395.

Furfine, C. (2003). Interbank exposures: Quantifying the risk of contagion. Journal of Money, Credit, and Banking, 35(1), 111-128.

Gabbi, G., Iori, G., Jafarey, S., \& Porter, J. (2015). Financial regulations and bank credit to the real economy. Journal of Economic Dynamics and Control, 50, 117-143.

Gençay, R., \& Selçuk, F. (2006). Overnight borrowing, interest rates and extreme value theory. European Economic Review, 50(3), 547-563.

In't Veld, D., \& van Lelyveld, I. (2014). Finding the core: Network structure in interbank markets. Journal of Banking \& Finance, 49(C), 27-40.
König, M. D., Tessone, C. J., \& Zenou, Y. (2014). Nestedness in networks: A theoretical model and some applications. Theoretical Economics, 9(3), 695-752.

Langfield, S., Liu, Z., \& Ota, T. (2014). Mapping the UK interbank system. Journal of Banking \& Finance, 45(C), 288-303.

Lelyveld, I., \& Liedorp, F. (2006). Interbank contagion in the Dutch banking sector: A sensitivity analysis. International Journal of Central Banking, 2(2).

Martinez-Jaramillo, S., Alexandrova-Kabadjova, B., Bravo-Benitez, B., \& SolorzanoMargain, J. P. (2014). An empirical study of the Mexican banking system's network and its implications for systemic risk. Journal of Economic Dynamics and Control, 40, 242-265.

Montagna, M., \& Kok, C. (2016). Multi-layered interbank model for assessing systemic risk. Kiel Working Papers 1873. Kiel Institute for the World Economy.

Silva, T. C., de Souza, S. R. S., \& Tabak, B. M. (2016). Network structure analysis of the Brazilian interbank market. Emerging Markets Review, 26, 130-152.

Upper, C. (2011). Simulation methods to assess the danger of contagion in interbank markets. Journal of Financial Stability, 7(3), 111-125.

Upper, C., \& Worms, A. (2004). Estimating bilateral exposures in the German interbank market: Is there a danger of contagion? European Economic Review, 48(4), 827-849. 